\title{
JE LI PRETHODNI POSTUPAK DOVEO DO KONCENTRACIJE I KRAĆEG TRAJANJA PARNIĆNOG POSTUPKA?
}

Dr. sc. Juraj Brozović*

UDK: $347.922 .1(497.5$

$347.932(497.5)$

DOI: 10.3935/zpfz.71.5.05

Izvorni znanstveni rad

Primljeno: prosinac 2021.

Nakon više od deset godina primjene pravila o prethodnom postupku, koja su bila predmetom većeg broja novela Zakona o parničnom postupku, postoji potreba da se preispita je li takva postupna strukturna promjena doista dovela do koncentracije te kraćeg trajanja postupka uz održavanje manjeg broja ročišta. Službeni podatci koje objavljuje Ministarstvo pravosuđa RH odnosno Vrhovni sud RH ne mogu dati odgovor na pitanje koliko i zašto traje postupak, koliko traju pojedini njegovi stadiji te koliko se u postupku zakazuje ročišta. Naše istraživanje nudi inovativnu metodologiju te prikazuje rezultate opsežnog empirijskog istraživanja koje, s jedne strane, uzima u obzir stvarne podatke o trajanju postupka i broju ročišta iz sustava eSpis te, s druge strane, analizom reprezentativnog uzorka predmeta najvećeg hrvatskog općinskog suda nastoji identificirati potencijalne uzročnike neučinkovitih postupaka. Naposljetku predlažu se nužne izmjene pravila o prethodnom postupku, ali i mentaliteta sudaca, odvjetnika i drugih pravnih profesionalaca koji sudjeluju u postupku.

Ključne riječi: prethodni postupak, empirijsko istraživanje, trajanje postupka, broj ročišta, lojalna suradnja, razmjernost

* Dr. sc. Juraj Brozović, asistent Pravnog fakulteta Sveučilišta u Zagrebu, Trg Republike Hrvatske 3, 10000 Zagreb; jbrozovic@pravo.hr;

ORCID ID: orcid.org/0000-0003-2362-4580 


\section{UVOD**}

U Zakonu o parničnom postupku (dalje u tekstu: ZPP)1 od 2008. u sporovima male vrijednosti, a od 2013. u redovnom parničnom postupku postoji tzv. prethodni postupak kao poseban pripremni stadij. Uveden je u procesu pristupanja Republike Hrvatske (dalje u tekstu: RH) Europskoj uniji (dalje u tekstu: EU) na tragu nastojanja da se ubrza i poveća učinkovitost sudskih postupaka. Na njega su se nadovezala pravila o procesnim prekluzijama, što je zajedno trebalo dovesti do koncentracije i kraćeg trajanja postupka uz zakazivanje manjeg broja ročišta. ${ }^{2}$ Takav je posebni procesni stadij uveden bez strukturirane empirijske analize funkcioniranja prvostupanjskog parničnog postupka i pojedinih njegovih stadija, a adekvatnog istraživanja nije bilo ni nakon njegova uvođenja. ${ }^{3}$ Službene statistike koje svake godine objavljuju Ministarstvo pravosuđa RH i Vrhovni sud RH pokazuju samo trendove $u$ pogledu primljenih i riješenih predmeta ${ }^{4}$, ali one ne svjedoče o funkcioniranju postupka u praksi, odnosno o trajanju pojedinih stadija, broju parničnih radnji, a još manje razlozima za tako uočeno stanje.

Empirijsko istraživanje, čiji su rezultati prikazani u ovom radu, služi općoj ocjeni funkcioniranja parničnog postupka, ali i znanstvenoj provjeri tvrdnje da prethodni postupak doista u praksi doprinosi koncentraciji i bržem provođenju postupka. Sama empirijska analiza sastoji se od dva dijela. Prvi dio započinje analizom dostupnih podataka o radu sudova iz spomenutih izvješća Ministarstva pravosuđa i Vrhovnog suda RH, dopunjenom podatcima iz sustava eSpis. S obzirom na to da prvi dio empirijskog istraživanja može samo odgovoriti na pitanje u kojoj je mjeri parnični postupak učinkovit te tako eventualno upozoriti na postojanje problema, drugi dio istraživanja deskriptivne je naravi i prikazuje pojavne oblike propuštanja sudova, parničnih stranaka i njihovih odvjetnika

** Empirijsko istraživanje prikazano u ovom radu sastavni je dio doktorske disertacije obranjene u listopadu 2021. na Pravnom fakultetu u Zagrebu, a posljednje poglavlje sažima najvažnije rezultate komparativnog istraživanja.

1 Službeni list SFRJ, br. 4/1977, 36/1977, 36/1980, 6/1980, 69/1982, 43/1982, 58/1984, 74/1987, 57/1989, 20/1990, 27/1990, 35/1991, Narodne novine, br. 53/1991, 91/1992, 112/1999, 129/2000, 88/2001, 117/2003, 88/2005, 2/2007, 84/2008, 96/2008, 123/2008, 57/2011, 148/2011, 25/2013, 89/2014 i 70/2019.

2 Bilić, V., Novela Zakona o parničnom postupku iz 2013., Informator, vol. 61, br. 6156, 6. ožujka 2013., str. 1 .

3 Uzelac, A., Delays and Backlogs in Civil Procedure. A (South) East European Perspective, Revista de Processo, vol. 39, br. 238, 2014., str. 58 - 59.

4 Bratković, M., Građansko pravosuđe u službi građana, u: Barbić, J. (ur.), Europska budućnost hrvatskog građanskog pravosuđa, HAZU, Zagreb, 2019., str. 179. 
koji su od utjecaja na učinkovito provođenje postupka na reprezentativnom uzorku konkretnih sudskih predmeta. Obje analize pokušavaju nadomjestiti uočeni manjak provjerljivih informacija o funkcioniranju hrvatskih sudova u okviru prvostupanjskog postupka.

Naposljetku se, umjesto zaključka, daju preporuke o poželjnoj strukturi i cilju prethodnog postupka, ulozi procesnih subjekata u njegovu provođenju te vanjskim čimbenicima o kojima treba voditi računa, uzimajući u obzir najbolje komparativne prakse.

\section{EMPIRIJSKI PODATCI O FUNKCIONIRANJU PRETHODNOG POSTUPKA U SUDSKOJ PRAKSI}

\subsection{Metodološke napomene}

Da bi bilo moguće izvršiti provjeru osnovne teze da uvođenje posebnog pripremnog stadija u hrvatski prvostupanjski parnični postupak, uz naglašavanje sudske odgovornosti za upravljanje postupkom i uvođenje procesnih prekluzija za stranačka propuštanja u tom stadiju, dovodi do koncentracije postupka, što implicira njegovo brže provođenje i održavanje manjeg broja ročišta, potrebno je odgovoriti na sljedeća pitanja:

1. Koliko su u prosjeku trajali prvostupanjski postupci nakon stupanja na snagu Novele iz 2013.?

2. Koliko su trajali pojedini stadiji u prvostupanjskom postupku?

3. Koliko je u prosjeku održano ročišta u tim postupcima?

4. Koliki je vremenski razmak između održanih ročišta?

5. Jesu li trajanje postupaka i broj ročišta u korelaciji:

- s priljevom predmeta na sudove

- s veličinom suda

- s opterećenosti pojedinih sudaca i sudskih savjetnika

- s trenutkom zakazivanja ročišta

- s trajanjem pojedinog stadija te njegovim eventualnim ponavljanjem

- s činjenicom da je postupak provodio sudac ili savjetnik

- s činjenicom da je tijekom postupka došlo do presignacije predmeta na drugog suca ili savjetnika

- s brojem stranaka

- s činjenicom da su stranke bile zastupane 
- s brojem i trenutkom uručenja pisanih podnesaka stranaka

- s trenutkom iznošenja činjenica i dokaznih prijedloga

- s vrijednosti predmeta spora

- s problemima u provođenju dostave?

Odgovor ni na jedno od postavljenih pitanja nije bilo moguće dobiti proučavanjem službenih statistika i godišnjih izvješća koja objavljuju Vrhovni sud RH i Ministarstvo pravosuđa (i uprave). Većina traženih podataka, međutim, izravno je ili neizravno dostupna u elektroničkom sustavu Ministarstva pravosuđa eSpis, koji je izradio i koji održava IBM. Od 2015. obvezni su koristiti se njime svi općinski sudovi, što nam je omogućilo zbirni pregled, a zatim i analizu prikupljenih podataka, nažalost bez mogućnosti usporedbe s ranijim rezultatima.

Kako bi se dobio što sustavniji i širi pregled podataka o postupanju sudova u parničnim predmetima, od Ministarstva pravosuđa zatraženi su podatci iz sustava eSpis za parnične predmete oznake P, Povrv, Pr, P Ob, Ps, Psp, Pn, Pu P i $\mathrm{Pl}^{5}$ koji su riješeni od 2015. do 2019. na svim općinskim sudovima u RH. Zatražen je i podatak o datumu početka i završetka postupka, o vrsti spora i njegovoj vrijednosti, o tome je li postupak provodio sudac ili sudski savjetnik, o vrsti odluke kojom je postupak dovršen, o broju održanih i odgođenih ročišta, o tome jesu li stranke bile zastupane od strane punomoćnika, o tome je li izjavljena žalba te, u slučaju da jest, o tome kakvu je odluku donio drugostupanjski sud.

Iz dobivenih podataka su zatim izdvojeni predmeti za koje se s dovoljnim stupnjem sigurnosti moglo zaključiti da su se u njima primjenjivala pravila redovnog parničnog postupka te pravila u sporovima male vrijednosti ${ }^{6}$, pa je analiza ograničena na predmete upisnika P, Pn, Ps i Pu P. Međutim, da bismo doista dobili uzorak predmeta koji se ne odnosi na posebne postupke u kojima je propisano bitno drukčije postupanje ili u kojima ne postoji klasični pripremni

5 Riječ je o općem parničnom upisniku, upisniku predmeta proslijeđenih od javnog bilježnika po prigovoru na rješenje o ovrsi na temelju vjerodostojne isprave, upisniku za radne sporove, upisniku za obiteljske sporove, upisniku stambenih sporova, upisniku predmeta smetanja posjeda, upisniku predmeta naknade štete, pomoćnim parničnim spisima te upisniku za platne naloge.

6 Iako bi bilo relevantno analizirati postupanje sudova i u ostalim posebnim postupcima, tema ovog istraživanja uvjetuje ograničenje analize na podatke o postupanju parničnih sudova u redovnom parničnom postupku i sporovima male vrijednosti. Uključivanje postupaka u sporovima male vrijednosti važno je zbog posebnog režima procesnih prekluzija i teme razmjernosti, ali i zbog faktične nemogućnosti lakog i pouzdanog izdvajanja tih predmeta. Sporovi male vrijednosti, naime, nemaju poseban upisnik, što znači da bi bilo potrebno pouzdati se u nepouzdane podatke o vrsti predmeta i njegovoj vrijednosti. 
stadij, iz općeg upisnika P trebalo je isključiti i niz predmeta koji su se u naznaci njihove vrste referirali na radno pravo (otkaz, postojanje radnog odnosa, isplata, naknada štete, ostala materijalna davanja, kolektivni ugovor, mobbing, diskriminacija na radnom mjestu i ostali radnopravni predmeti), obiteljsko pravo (razvod braka, poništenje braka, odlučivanje o roditeljskoj skrbi, utvrđivanje i osporavanje majčinstva i očinstva, uzdržavanje djeteta, uzdržavanje bračnog ili izvanbračnog druga te trećih osoba i ostali obiteljskopravni predmeti), platni nalog, predmete proslijeđene po javnom bilježniku u povodu prigovora protiv platnog naloga te smetanje posjeda. Iz istih je razloga iz tog upisnika trebalo isključiti i predmete čija naznaka vrste ne sugerira primjenu pravila posebnih postupaka, ali je u eSpisu zabilježeno da su dovršeni presudom povodom platnog naloga, rješenjem u obliku platnog naloga te rješenjem o smetanju posjeda. U razdoblju od 2015. do 2019. izdvojeno je 246.997 takvih predmeta.

Ovakvo sužavanje relevantnih predmeta omogućilo nam je da za svaku promatranu godinu dobijemo precizan podatak koliko su dovršeni postupci trajali ovisno o vrsti donesene sudske odluke i neovisno o tome kad su pokrenuti. ${ }^{7} \mathrm{Na}$ temelju tih podataka, međutim, nije bilo moguće evaluirati učinke Novele iz 2013. Idući korak, stoga, bio je isključiti predmete koji nisu pokrenuti za vrijeme njezina važenja, odnosno u razdoblju između 1. travnja 2013. i 31. kolovoza 2019. Zatim je, u svrhu dobivanja relevantnih i usporedivih podataka o broju ročišta, bilo potrebno ograničiti pretragu isključivo na predmete dovršene kontradiktornom presudom. ${ }^{8}$ Iz istog je razloga bilo potrebno spojiti predmete koji su prekinuti pa nastavljeni pod novim poslovnim brojem te ih $\mathrm{u}$ analizi promatrati kao jedan predmet. ${ }^{9}$ Kako bi se osiguralo metodološki prihvatljivo uspoređivanje podataka svih sudova, u reakciji na dvije reorganizacije pravosudne mreže, predmeti sudova koji su 2015. postali stalne službe, odnosno stalnih službi koje su 2018. postale sudovi, pribrojani su onom sudu koji je postojao pretežiti broj godina u promatranom razdoblju. ${ }^{10}$ Nadalje, kako bi se u određivanju vremena

7 Vidi infra pod 2.2.1.

8 To je učinjeno kombiniranom upotrebom naznake vrste odluke (ograničivši je samo na kategoriju "presuda") te posljednje sudske radnje (ograničivši je samo na "ročište za objavu”).

9 Broj ročišta uključuje samo ročišta koja su doista održana, uz isključivanje svakog njihova dvostrukog prikazivanja. Ako je na primjer po dovršetku pripremnog ročišta odmah započela i glavna rasprava, to se ročište u eSpisu brojalo kao jedno ročište te je tako i prikazano u našoj analizi.

10 Tako ćemo na primjer sve predmete prikazati kao predmete Općinskog suda u Puli iako je u dijelu 2015. i u 2019. dio tih predmeta pripadao Općinskom sudu u Pazinu. Ako je došlo do ustupanja predmeta uslijed reorganizacije, vodili smo računa da isti predmet ne bude analiziran dvaput. 
rješavanja predmeta u obzir uzimali isključivo postupanje prvostupanjskih sudova koje ne ovisi o postupanju drugostupanjskih sudova, u uzorak su uključeni samo predmeti u kojima protiv sudske odluke nije izjavljena žalba ili je ona, iz razloga procesne ili materijalnopravne naravi, nedvojbeno bila neuspješna, što je vidljivo iz naznake odluke drugostupanjskog suda. ${ }^{11}$

Tako je u razdoblju od 2015. do 2019. dobiven uzorak od ukupno 43.473 nova predmeta koji su riješeni kontradiktornom presudom. ${ }^{12} \mathrm{U}$ ovome je uzorku bilo moguće po promatranim godinama analizirati ukupno trajanje prvostupanjskog postupka i broj ročišta ${ }^{13}$ koje smo zatim mogli pokušati dovesti u korelaciju s pojedinim čimbenicima poput veličine suda, priljeva predmeta, opterećenosti sudaca i sudskih savjetnika (engl. CPJ - Case per Judge), vrijednosti predmeta spora i činjenicom zastupanja jedne ili obje stranke. ${ }^{14}$ Korelacija je izračunavana CORREL funkcijom u Microsoft Excelu, a njezin stupanj izražen je Spearmanovim koeficijentom $\left(r_{s}\right) \cdot{ }^{15}$ Vrijednost Spearmanova koeficijenta korelacije kreće se od +1 do -1 . Predznak koeficijenta upućuje nas na smjer korelacije (je li pozitivna ili negativna). Korelacija je zanemariva ako iznosi između 0 i 0,24, slaba između 0,25 i 0,49 , umjerena između 0,50 i 0,74 , a snažna između 0,75 i $1 .{ }^{16}$

Prilikom analize podataka uočen je određeni stupanj nekonzistentnosti u načinu unošenja podataka o predmetima na pojedinim sudovima, ali i neočekivani rezultati poput onog da je na jednom manjem sudu predmet dovršen kontradiktornom presudom u samo 16 dana od podnošenja tužbe u dva održana ročišta. Nakon provjere podataka s Ministarstvom pravosuđa utvrdili smo da je predmet doista dovršen u tako kratkom vremenu, ali je veći dio tužbenog

11 Tako su uključeni predmeti u kojima je izjavljena žalba, ali je drugostupanjski postupak dovršen remisornim rješenjem, rješenjem o odbačaju žalbe te rješenjem o odbijanju žalbe i potvrđivanju prvostupanjske odluke.

12 Kad infra pod 2.2. govorimo o novim predmetima, riješenim kontradiktornom presudom, onda govorimo o predmetima iz e-Spisa oznake P, Pn, Ps i Pu P koji su pokrenuti za vrijeme važenja Novele iz 2013., koji su riješeni (kontradiktornom) presudom te u kojima je posljednja radnja ročište za objavu odluke.

13 Trajanje je izraženo u danima te mjesecima, pri čemu je kao prosječni broj dana u mjesecu uzet broj od 30 dana. Vidi infra pod 2.2.1.

14 Vidi infra pod 2.2.2.

15 Spearmanov koeficijent odbran je zbog nelinearne distribucije podataka. Da bi bilo moguće izračunati ga uz pomoć CORREL funkcije koja računa Pearsonov koeficijent (inače prikladan za linearnu distribuciju), prethodno je trebalo rangirati unose, što je učinjeno funkcijom $R A N K . A V G$.

16 Udovičić, M. et al., Što treba znati kada izračunavamo koeficijent korelacije?, Biochemia Medica, vol. 17, br. 1, 2007., str. 12 - 13. 
zahtjeva bio priznat pa je odmah po zaključenju pripremnog ročišta moglo biti održano ročište za glavnu raspravu nakon kojeg je na posebnom ročištu objavljena presuda. S obzirom na to da je jedini u cijelosti pouzdan način provjeravanja pouzdanosti podataka vršenje takvog neposrednog uvida u svaki predmet u sustavu eSpis, veličina našeg uzorka uvjetovala je potrebu da pouzdanost provjerimo na drugi način. Odlučili smo se na upotrebu Benfordova zakona. ${ }^{17}$ Pouzdanost podataka o trajanju postupaka u danima potvrđena je pravilno distribuiranom Benfordovom krivuljom (Graf 1.1):

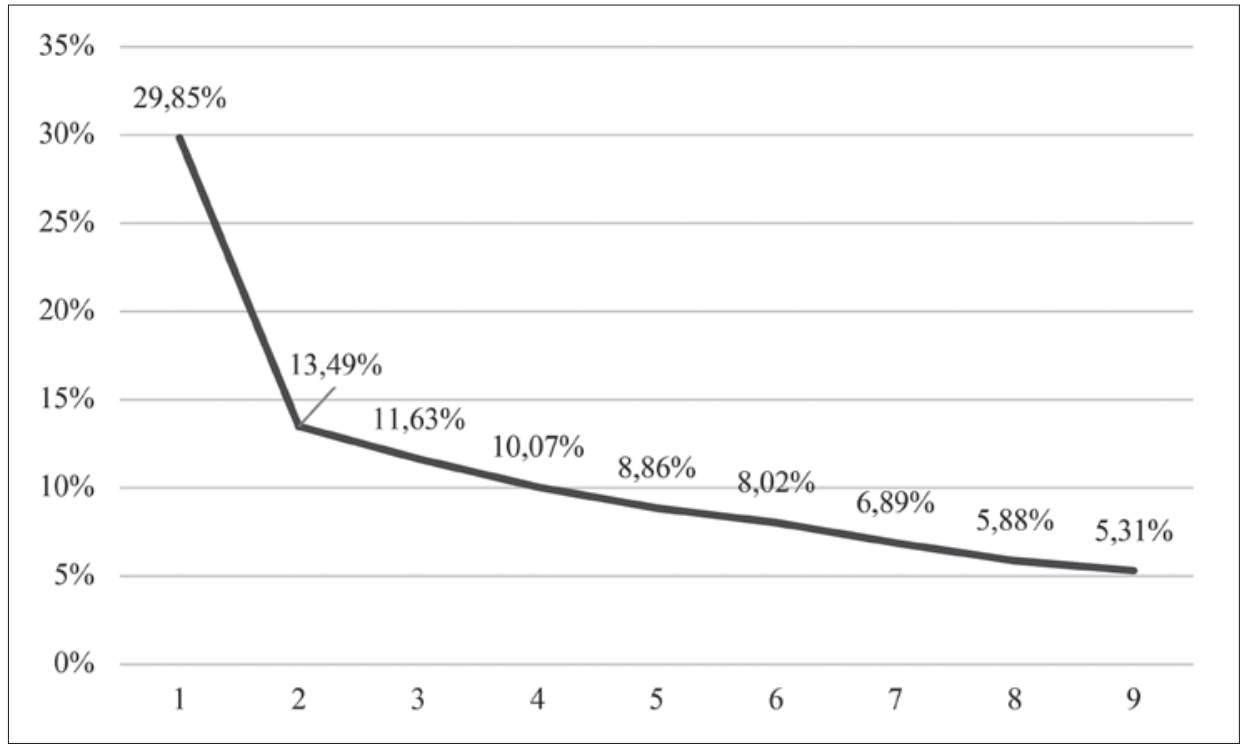

Graf I.I - Provjera podataka o trajanju postupaka upotrebom Benfordove krivulje

17 Prema Benfordovu zakonu u popisu brojeva koji se pojavljuju prirodno, bez ljudske intervencije, gotovo trećina brojeva započet će znamenkom l (30,1\%), manje od petine znamenkom 2 (17,6 \%), oko desetine znamenkom 3 (12,5\%) i 4 (9,7\%), oko dvadesetine znamenkom 5 (7,9\%), uz daljnji pad pojavnosti prema znamenci 9 (6,7 \% za znamenku 6, 5,8 \% za znamenku 7, 5,1 \% za znamenku 8 te 4,6 \% za znamenku 9). Više o pojmu Benfordova zakona vidi u: Basrak, B.; Varga, I., Benfordov zakon, Math.e, vol. 23, br. 1, 2013. Nažalost, i dalje ne možemo sa sigurnošću tvrditi da je u pojedinim predmetima svaki unos bio ispravan i da podatci koji značajno odudaraju od prosjeka nisu rezultat pogrešnog računalnog prikaza pojedinih rezultata. Pravilno distribuirana Benfordova krivulja, ipak, potvrđuje nam da su takva odstupanja iznimka koja nije od značajnijeg utjecaja na pravilnost prikaza prosječnih vrijednosti. 
Analiza podataka prikupljenih od Ministarstva pravosuđa omogućila nam je da dobijemo pravu sliku o brzini postupanja općinskih sudova i broju održanih ročišta koju možemo usporediti s podatcima iz javno dostupnih izvješća. No, to i dalje nije dovoljno za odgovor na sva naša istraživačka pitanja. Na temelju tih podataka ne znamo koliko su trajali pojedini stadiji, koliki je stvarni razmak između ročišta ni iz kojeg razloga su ona odgađana. Podatci o trajanju pojedinog stadija i stvarnom razmaku između ročišta mogli bi se iskazati u onim predmetima u kojima su u eSpisu precizno navedena sva održana ročišta na kojima je ujedno jasno naznačena njihova vrsta, no i tu bi zaključci mogli biti pogrešni ako su na istom ročištu poduzete radnje koje sadržajno pripadaju glavnoj raspravi ili ako vrsta ročišta nije pravilno označena. Zato bi se, kao i slučaju utvrđivanja razloga odgoda ročišta, ti podatci mogli provjeriti jedino neposrednim uvidom u eSpis u svakome od 43.514 predmeta u uzorku.

Nadalje, povezivanje rezultata s mogućim uzrocima na temelju pukih zbirnih podataka iz eSpisa ograničenog je dosega. Korelacija je mogla odgovarajućim koeficijentom biti iskazana samo u odnosu na vrijednost predmeta spora i opterećenost sudaca (CPJ). Međutim, zbirni podatci pružili su nam informaciju je li postupak provodio sudac ili sudski savjetnik te jesu li u predmetu bile zastupana jedna stranka, obje stranke ili nijedna stranka. Utjecaj tih čimbenika mogao je biti ocjenjivan na posredan način, usporedbom trajanja postupaka i broja ročišta održanih u predmetima ovisno o prisutnosti tih čimbenika. Utjecaj drugih čimbenika, koji bi mogli biti u korelaciji s trajanjem postupka i brojem ročišta, nije mogao biti ocijenjen jer ti podatci nisu bili dostupni ili skupno prikazivi.

Precizniji odgovor na sva ta pitanja zahtijevao bi opsežno istraživanje sadržaja spisa svih općinskih sudova koji bi trebali biti nasumično odabrani u broju koji bi jamčio reprezentativnost i jednaku raspodjelu između svih sudova, ali $\mathrm{uz}$ istodobno uzimanje u obzir njihove veličine. $\mathrm{S}$ obzirom na to da se $\mathrm{u}$ promatranom razdoblju većina radnji, bez obzira na korištenje $e$ Spisa, ipak i dalje bilježila u pisanom obliku, takvo bi istraživanje zahtijevalo logistiku i vremenski angažman koji nadilazi ovo istraživanje. U budućnosti bi obvezna elektronička dostava mogla olakšati provođenje istraživanja takve vrste.

U želji da u okviru empirijskog istraživanja opišemo kako se barem dio sudaca, sudskih savjetnika, stranaka i njihovih odvjetnika prilagodio zasebnom pripremnom stadiju i novim zadaćama u okviru prvostupanjskog parničnog postupka nakon Novele iz 2013., te time makar u ograničenom obliku odgovorimo na preostala postavljena istraživačka pitanja, odlučili smo se na pregled predmeta Općinskog građanskog suda u Zagrebu na unaprijed određenom uzorku. Svrha ovog dijela istraživanja bila je utvrditi koje aktivne i pasivne parnične radnje suda, stranaka i njihovih punomoćnika dovode do postupka 
koji bismo, zbog njegova dugog trajanja ili velikog broja ročišta, mogli smatrati neučinkovitim. Logika i smisao, dakle, nisu bili utvrditi koliko često ili u kojem broju predmeta su na području čitave države te parnične radnje bile prisutne. Drugim riječima, na temelju ovog dijela istraživanja nije moguće donositi opće zaključke o općem postupanju sudova u RH, čak ni o općem postupanju sudaca i savjetnika Općinskog građanskog suda u Zagrebu. Uzorak je prigodan, odnosno reprezentativan samo u odnosu na postupanje sudaca i savjetnika Općinskog građanskog suda u Zagrebu u unaprijed određenoj vrsti predmeta, ali rezultati mogu dovesti u vezu neučinkovite postupke s propuštanjem sudaca, stranaka i njihovih punomoćnika. Nepoželjne parnične radnje trebale bi biti jednako nepoželjne na čitavom teritoriju RH pa su rezultati ovog dijela istraživanja relevantni i za druge sudove.

U populaciju su uključeni predmeti Općinskog građanskog suda u Zagrebu oznake P i Pn koji su u 2015., 2016. i 2017. dovršeni kontradiktornom presudom, u kojima su zakazana više od četiri ročišta te koji nisu ponovljeni u povodu prihvaćene žalbe. ${ }^{18}$ Kako bismo bili sigurni da je doista riječ o predmetima koji su riješeni kontradiktornom presudom, trebalo je isključiti one predmete u kojima posljednja sudska radnja nije bilo ročište za objavu odluke. U uzorku je bilo ukupno 3335 predmeta $(\mathrm{N}=3335)$ pa smo primjenom matematičke formule za izračun reprezentativnog uzorka na poznatoj populaciji (Formula 1.1) utvrdili da nam je, uz standardnu pogrešku od $5 \%(\mathrm{e}=0,05)$, proporciju s najvećom varijancom od $50 \%(\mathrm{p}=0,5)$ te koeficijent pouzdanosti od $95 \%(\mathrm{z}=1,96)$, za reprezentativnost bilo potrebno pregledati 345 predmeta $\left(n^{\prime}=344.479\right) .{ }^{19}$

Formula I.I - Izračun reprezentativnog uzorka na poznatoj populaciji

$$
n^{\prime}=\frac{\frac{z^{2 *} p^{*}(1-p)}{e^{2}}}{1+\frac{z^{2 *} \mathrm{p}^{*}(1-\mathrm{p})}{e^{2 *} \mathrm{~N}}}
$$

18 U postupku u pravilu ne bi biti smjelo biti održano više od jednog pripremnog ročišta (čl. 291. ZPP-a), jednog ročišta za glavnu raspravu (čl. 293. ZPP-a) i jednog ročišta za objavu presude (čl. 335. ZPP-a).

19 Ovo je standardna formula u statistici za izračun reprezentativnog uzorka na poznatoj populaciji. Njime se koriste i brojni javno dostupni online alati poput mrežnog servisa Surveymonkey. Vidi https://www.surveymonkey.com/mp/sample-size-calculator/\#: :text=Sample\%20size\%20is\%20the\%20number,or\%20behavior\%20 you\%20care\%20about (1. prosinca 2021). 
S obzirom na to da smo htjeli postići jednaku zastupljenost predmeta dovršenih u svakoj od tri promatrane godine, pregledan je i veći broj predmeta, ukupno njih 348. Predmeti su podijeljeni u šest skupina od 58 predmeta (oznake P i Pn riješenih u 2015., 2016. i 2017. godini). Odabrani su metodom jednostavnog slučajnog uzorka da osiguramo objektivnost rezultata. ${ }^{20} \mathrm{Iz}$ istih razloga nisu unaprijed ograničavani predmeti s obzirom na njihovu vrstu.

Vrsta predmeta u uzorku mogla se nedvojbeno utvrditi tek nakon neposrednog uvida u sve spise. Najveći broj predmeta odnosio se na postupke radi isplate i naknade imovinske štete prouzrokovane prometnim nezgodama, no u uzorak su uključeni i brojni drugi predmeti različita sadržaja (Graf 1.2), čime je uzorak dobio širinu i veću relevantnost.

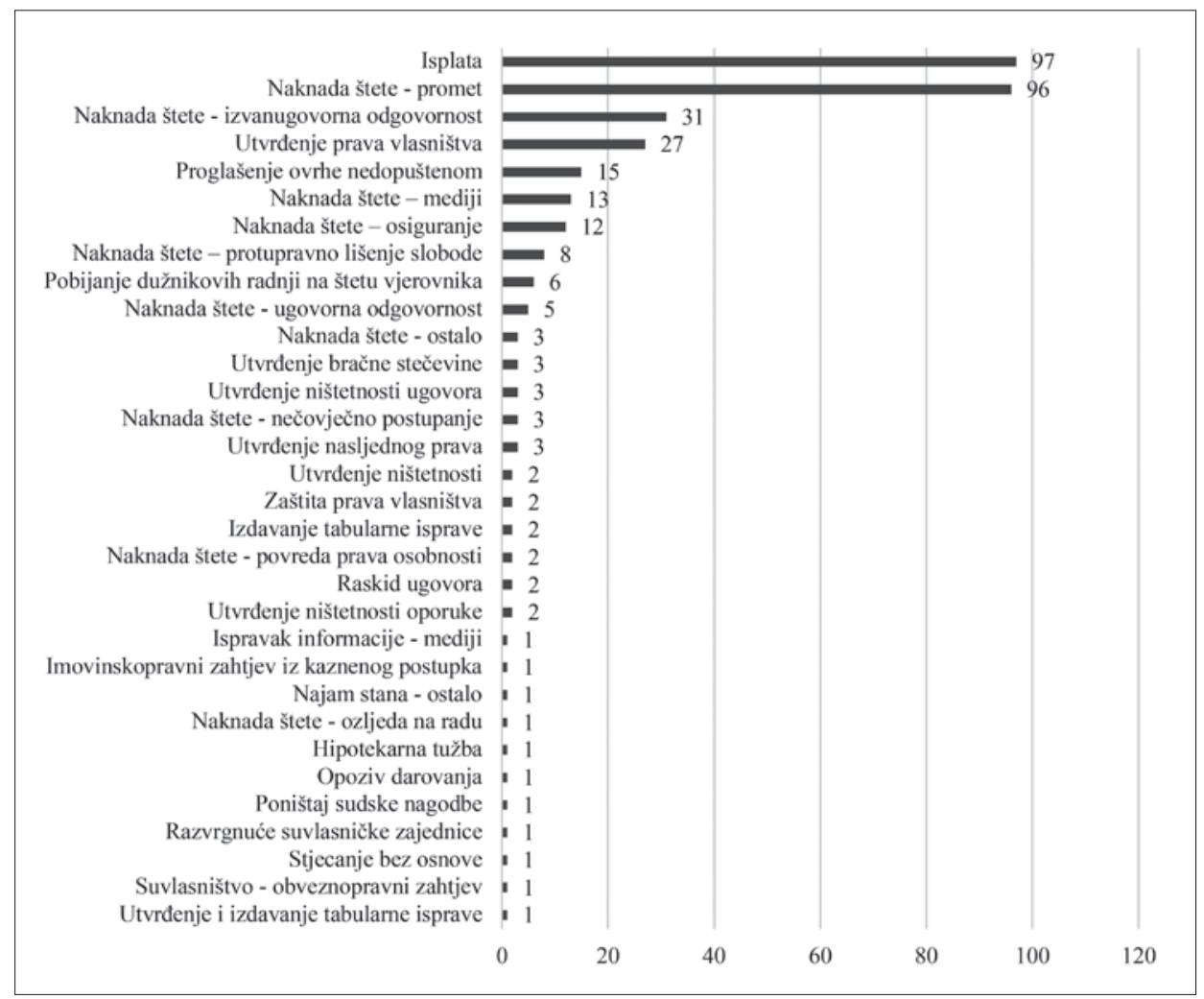

Graf 1.2 - Vrsta predmeta u uzorku

20 Predmeti su odabrani korištenjem RAND() funkcije u Microsoft Excelu. U svakoj kategoriji predmeta odabrano je prvih 58 predmeta koji udovoljavaju navedenim uvjetima. 
Pregled spisa omogućio je detaljniji opis predmeta i postupanja svih procesnih subjekata u tim predmetima pa je pritom precizno i sistematično bilježen

- datum podnošenja tužbe

- datum slanja tužbe na pisani odgovor

- datum zakazivanja pripremnog ročišta

- datum primitka pisanog odgovora na tužbu

- datum pripremnog ročišta u pozivu za pripremno ročište

- datum pripremnog ročišta koje se doista održalo (na kojem se raspravljalo)

- datum pripremnog ročišta na kojem je zaključen prethodni postupak

- datum prvog ročišta za glavnu raspravu

- datum zaključenja glavne rasprave

- datum ročišta za objavu odluke

- datum preotvaranja glavne rasprave

- datum zaključenja preotvorene glavne rasprave

- razlog preotvaranja glavne rasprave

- broj odgoda ročišta po pojedinoj vrsti ročišta, zajedno s razlozima za te odgode

- je li bilo problema s dostavom tužbe tuženiku i iz kojih razloga

- je li bilo problema s dostavom u naknadnom tijeku postupka i iz kojih razloga

- je li postupak provodio sudac ili sudski savjetnik

- je li u postupku došlo do presignacije predmeta na drugog suca ili savjetnika

- koliko je svaka stranka podnijela pisanih podnesaka i koji je bio njihov sadržaj

- broj tužitelja i tuženika

- jesu li jedna, obje ili nijedna od stranaka bile zastupane

- vrijednost predmeta spora.

Bilježenje tih podataka omogućilo nam je precizni izračun trajanja postupka i broja održanih ročišta, trajanja pojedinih stadija u prvostupanjskom postupku te razmaka između ročišta. ${ }^{21}$ Ostali podatci koje smo prikupili pomažu nam

${ }^{21}$ Trajanje je i u ovom dijelu istraživanja izraženo u danima te mjesecima, pri čemu je i ovdje kao prosječni broj dana u mjesecu uzeto 30 dana. Vidi infra pod 2.3.1 2.3.2. 
dovesti takve rezultate u korelaciju s pojedinim parničnim radnjama suda, stranaka i njihovih punomoćnika te drugim čimbenicima, pri čemu ih zbog ovakvog pristupa možemo ne samo kvantificirati, već i opisati. ${ }^{22}$ Drugi dio empirijskog istraživanja, dakle, osim kvantitativne sadržava i deskriptivnu analizu, čime smatramo da smo u dovoljnoj mjeri zaobišli opasnost "zavodljive kvantifikacije" koja bez opisivanja postupanja procesnih subjekata može dovesti do pogrešnih zaključaka o radu sudova. ${ }^{23}$

\subsection{Istraživanje na uzorku predmeta svih općinskih sudova iz sustava eSpis}

2.2.1 Opći podatci o učinkovitosti postupanja na općinskim sudovima od 2015. do 2019.

2.2.1.1 Koliko traje prvostupanjski parnični postupak na općinskim sudovima?

U izvješćima Ministarstva pravosuđa moguće je, po metodologiji CEPEJ-a, pratiti trendove priljeva i rješavanja predmeta, na temelju čega je moguće izračunati očekivano trajanje postupka (engl. Disposition Time).$^{24}$ Povoljna stopa rješavanja predmeta u 2015., 2016. i 2018. rezultirala je očekivanim trajanjem postupka u prosjeku nešto manje od 14 mjeseci. Manje riješenih predmeta u 2017. uvjetovalo je i duže očekivano trajanje postupka koje je u toj godini iznosilo gotovo tri mjeseca više, da bi u 2019. poraslo na najvišu razinu u promatranom razdoblju, na 544 dana ili gotovo 18 mjeseci (Tablica 1.1).

22 Vidi infra pod 2.3.3.

23 Economides, K.; Haug, A. A.; McIntyre, J., Toward Timelessness in Civil Justice, Monash University Law Review, vol. 41, br. 2, 2015., str. 421 - 422; Merry, S. A., The Seductions of Quantification. Measuring Human Rights, Gender Violence, and Sex Trafficking, University of Chicago Press, Chicago, London, 2016., str. 2 seqq.

24 Podatak o očekivanom trajanju postupka dobiva se tako da se broj predmeta u rješavanju podijeli s brojem riješenih predmeta te pomnoži s prosječnim brojem dana u godini. Brojka, dakle, odražava aproksimaciju s obzirom na trendove rješavanja predmeta. European judicial systems: Efficiency and quality of justice, CEPEJ STUDIES, no. 26, 2018., str. 238. 
Tablica I.I - Broj parničnih predmeta na svim općinskim sudovima

\begin{tabular}{|r|r|r|r|r|r|}
\hline & primljeno & riješeno & neriješeno & CR & DT \\
\hline 2015. & 119117 & 139397 & 144373 & $117,0 \%$ & 378 \\
\hline 2016. & 98665 & 118258 & 124746 & $119,9 \%$ & 385 \\
\hline 2017. & 102000 & 102105 & 118818 & $100,10 \%$ & 425 \\
\hline 2018. & 90.657 & 100.524 & 107.504 & $110.88 \%$ & 390 \\
\hline 2019. & 107.893 & 86.493 & 128.895 & $80.17 \%$ & 544 \\
\hline
\end{tabular}

Podatci o očekivanom trajanju postupka ne mogu se poistovjetiti s njegovim stvarnim trajanjem, što pokazuju podatci iz eSpisa o trajanju dovršenih postupaka u redovnom parničnom postupku i sporovima male vrijednosti, neovisno o tome kad su pokrenuti (Tablica 1.2).

Tablica 1.2 - Trajanje postupaka neovisno o načinu rješavanja i kad je postupak pokrenut

\begin{tabular}{|l|c|c|c|c|c|c|c|c|c|c|}
\hline \multicolumn{1}{|c|}{ trajanje u danima } & 2015. & uzorak & 2016. & uzorak & 2017. & uzorak & 2018. & uzorak & 2019. & uzorak \\
\hline $\begin{array}{l}\text { kontradiktorna } \\
\text { presuda }\end{array}$ & 1494 & 27190 & 1579 & 22253 & 1777 & 44767 & 1524 & 20967 & 1445 & 17240 \\
\hline $\begin{array}{l}\text { presuda - bez } \\
\text { održavanja rasprave }\end{array}$ & 383 & 84 & 471 & 57 & 392 & 106 & 441 & 59 & 243 & 38 \\
\hline $\begin{array}{l}\text { presuda - na temelju } \\
\text { odricanja }\end{array}$ & 1229 & 333 & 1336 & 346 & 1303 & 486 & 1228 & 415 & 1152 & 386 \\
\hline $\begin{array}{l}\text { presuda - na temelju } \\
\text { priznanja }\end{array}$ & 422 & 2373 & 452 & 1878 & 435 & 2433 & 383 & 1931 & 318 & 1604 \\
\hline $\begin{array}{l}\text { presuda - zbog } \\
\text { izostanka }\end{array}$ & 469 & 675 & 400 & 426 & 379 & 391 & 334 & 352 & 530 & 269 \\
\hline $\begin{array}{l}\text { presuda - zbog } \\
\text { ogluhe }\end{array}$ & 292 & 5571 & 277 & 4949 & 254 & 5528 & 269 & 5104 & 244 & 4305 \\
\hline sudska nagodba & 1056 & 3258 & 1192 & 3708 & 1183 & 6195 & 1102 & 3313 & 986 & 3222 \\
\hline $\begin{array}{l}\text { rješenje - apsolutna } \\
\text { nenadležnost }\end{array}$ & 615 & 87 & 893 & 42 & 840 & 88 & 678 & 26 & 578 & 35 \\
\hline $\begin{array}{l}\text { rješenje - mjesna } \\
\text { nenadležnost }\end{array}$ & 494 & 609 & 513 & 452 & 512 & 1648 & 416 & 44 & 252 & 952 \\
\hline $\begin{array}{l}\text { rješenje - } \\
\text { nenadležnost i } \\
\text { ustupanje predmeta } \\
\text { nadležnom sudu }\end{array}$ & 444 & 168 & 491 & 121 & 388 & 441 & 518 & 378 & 421 & 112 \\
\hline $\begin{array}{l}\text { rješenje - odbačena } \\
\text { tužba }\end{array}$ & 922 & 1174 & 1079 & 1003 & 1029 & 1965 & 1025 & 1028 & 999 & 867 \\
\hline $\begin{array}{l}\text { rješenje - stvarna } \\
\text { nenadležnost }\end{array}$ & 323 & 645 & 367 & 562 & 287 & 2415 & 276 & 491 & 261 & 447 \\
\hline $\begin{array}{l}\text { rješenje - povučena } \\
\text { tužba }\end{array}$ & 1110 & 9613 & 1293 & 9256 & 882 & 18496 & 1138 & 8212 & 1065 & 6657 \\
\hline
\end{tabular}


Promotrimo li pažljivije podatke po mjesecima, možemo uočiti da su postupci dovršeni jednostavnim procesnim rješenjima, poput rješenja o apsolutnoj nenadležnosti, riješeni u prosjeku unutar 20 mjeseci u 2015., 2018. i 2019., ali više od 28 mjeseci u 2016. i 2017. U istom je razdoblju za donošenje rješenja o relativnoj nenadležnosti trebalo između 9 i 17 mjeseci. ${ }^{25} \mathrm{U}$ svim promatranim godinama za donošenje rješenja o odbačaju tužbe trebalo je barem 30 mjeseci, dakle više od dvije i pol godine (Graf 2.l).

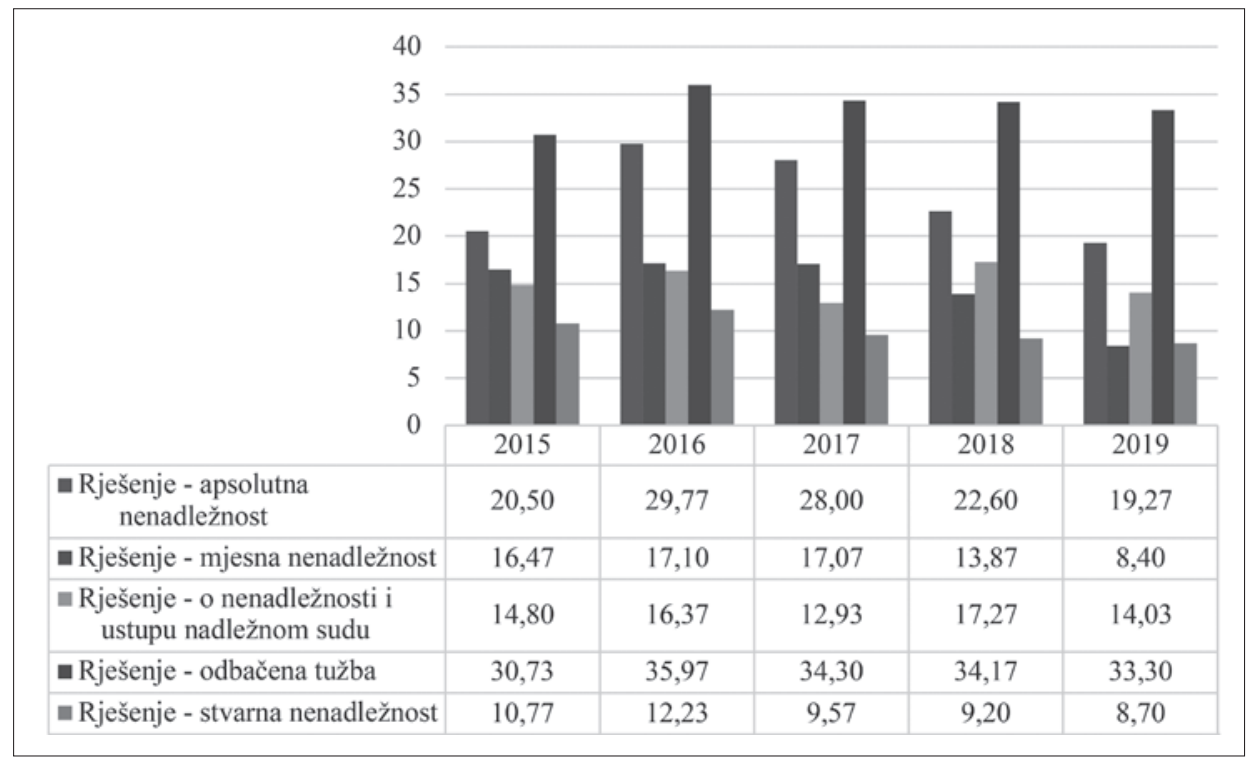

Graf 2.1 - Vrijeme donošenja procesnih odluka (u mjesecima)

Do sudske nagodbe u postupcima je dolazilo nakon što je u postupku proteklo više od dvije i pol godine, odnosno najmanje 32 mjeseca u 2019., odnosno najviše 39 mjeseci u 2016. i 2017. Vrijeme donošenja meritornih odluka ovisilo je o vrsti odluke. Vrijeme donošenja presuda zbog ogluhe palo je s gotovo 10 mjeseci u 2015. na nešto manje od 8 mjeseci u 2019. Presuda zbog izostanka samo se 2018. donosila unutar jedne godine, a 2019. za donošenje te vrste odluke trebalo je 17 mjeseci, odnosno više od godinu i pol dana. Do dispozi-

25 Nažalost, eSpis razlikuje tri vrste odluke koje se mogu povezati s relativnom nenadležnošću. Dok je za "Rješenje - mjesna nadležnost” i "Rješenje - stvarna nenadležnost” jasno o kojem je obliku nenadležnosti riječ, to nije slučaj s odlukama označenim “Rješenje - o nenadležnosti i ustupu nadležnom sudu”. U posljednjoj kategoriji ne znamo koliki se broj rješenja odnosi na stvarnu, a koliki na mjesnu nadležnost, no znamo pouzdano da je riječ o relativnoj nenadležnosti, što je dovoljno za uopćeni prikaz trajanja postupaka riješenih takvom vrstom odluke. 
tivnih presuda u pravilu je dolazilo nakon 10 do 15 mjeseci u slučaju presude na temelju priznanja, odnosno u prosjeku tri i pol godine u slučaju presude na temelju odricanja. Vrijeme donošenja kontradiktornih presuda raslo je od 49 mjeseci u 2015. do 59 u 2017., da bi zatim palo na 50 mjeseci u 2018., odnosno 48 mjeseci u 2019. U svakoj od promatranih godina, ipak, riječ je o prosječnom trajanju od više od četiri godine (Graf 2.2).

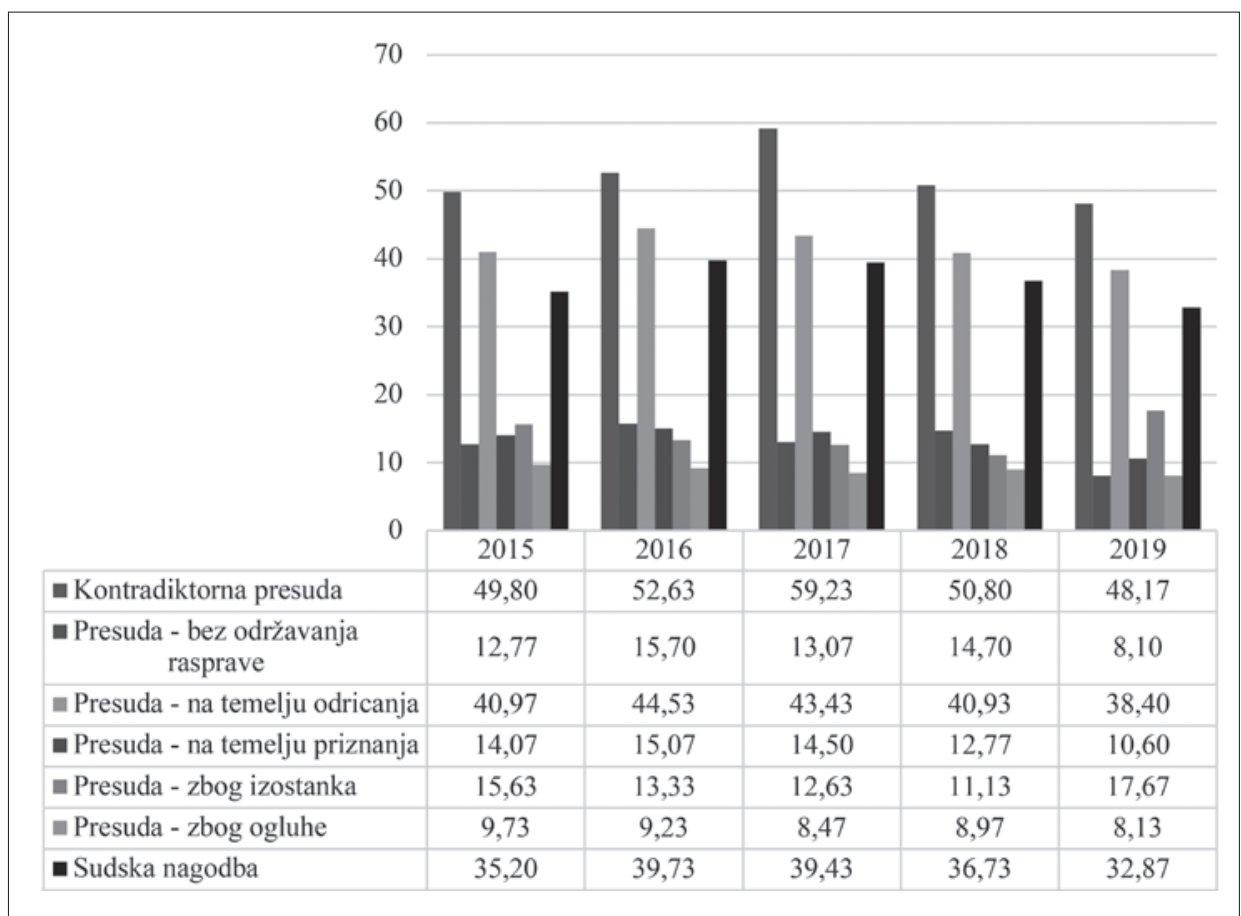

Graf 2.2 - Vrijeme donošenja meritornih odluka i sklapanja sudske nagodbe (u mjesecima)

Podsjećamo da se gore prikazani podatci odnose i na postupke koji su pokrenuti i po ZPP-u iz ranijih razdoblja pa podatak o trajanju postupka nije relevantan za ocjenu učinkovitosti postupka nakon Novele iz 2013.

Kad se u obzir uzme uzorak 43.437 predmeta koji su pokrenuti isključivo za vrijeme važenja Novele iz 2013., ali ujedno u istom razdoblju dovršeni kontradiktornom presudom, prosječno trajanje po godinama varira od jedne godine i jednog mjeseca u 2015. do više od dvije godine i jednog mjeseca u 2019., uz primjetan trend rasta (Graf 2.3). ${ }^{26}$

26 Za minimalno trajanje postupka u pojedinim godinama koje, čini se, odstupa od očekivanog trajanja postupka (poput četiri dana u 2017., vidi supra pod 2.1 Metodološke napomene (posebno bilj. 17)). 


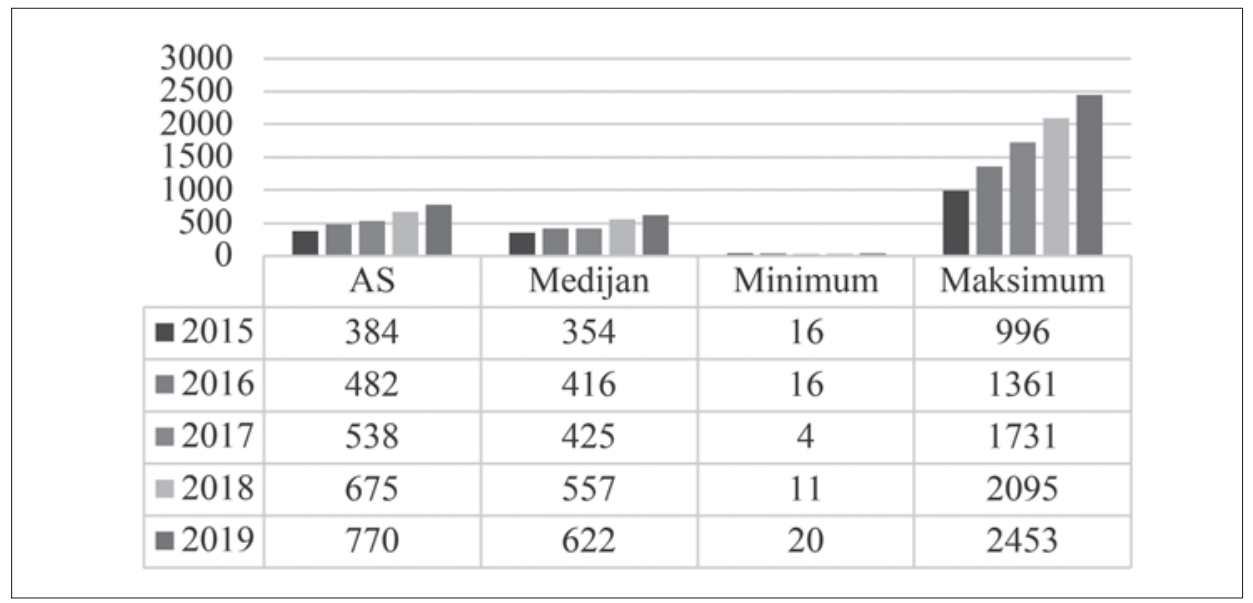

Graf 2.3 - Trajanje postupaka riješenih kontradiktornom presudom po pojedinim godinama

Gledano skupno u čitavom razdoblju, novi su postupci rješavani kontradiktornom presudom u prosjeku nakon 597, odnosno godinu i pol dana, ali raspon vremena rješavanja varira od samo četiri dana do čak šest godina i osam mjeseci (Tablica 1.3).

Tablica 1.3 - Trajanje postupaka riješenih kontradiktornom presudom u danima

\begin{tabular}{|c|c|}
\hline $2015 .-2019$. & trajanje u danima \\
\hline AS & 597 \\
\hline medijan & 474 \\
\hline minimum & 4 \\
\hline maksimum & 2453 \\
\hline uzorak & 43473 \\
\hline
\end{tabular}

Podatci o postotku predmeta riješenih u određenom broju mjeseci (Tablica 1.4) pokazuju da je relativno najveći broj predmeta (22,30 \%) riješen u roku od šest do dvanaest mjeseci. Isto tako, nešto manje od $16 \%$ predmeta riješeno je u razdoblju od manje od šest mjeseci. Ipak, gotovo dvije trećine predmeta $(61,95 \%)$ riješeno je nakon više od godine dana. 
Tablica 1.4 - Trajanje postupaka riješenih kontradiktornom presudom u mjesecima

\begin{tabular}{|c|c|}
\hline trajanje u mjesecima & postotak \\
\hline$>36$ & $14,86 \%$ \\
\hline $24-36$ & $16,40 \%$ \\
\hline $18-24$ & $13,07 \%$ \\
\hline $12-18$ & $17,61 \%$ \\
\hline $6-12$ & $22,30 \%$ \\
\hline $3-6$ & $11,54 \%$ \\
\hline $1-3$ & $4,11 \%$ \\
\hline$<1$ & $0,10 \%$ \\
\hline
\end{tabular}

2.2.1.2 Koliko se ročišta zakazuje u parničnim postupcima pred općinskim sudovima?

Kad je u pitanju broj ročišta u prvostupanjskom postupku, prosjek broja ročišta (Graf 2.4) u promatranom razdoblju varira od 3,29 $(\mathrm{m}=3)$ u 2015. do 4,46 u 2019. ( $\mathrm{m}=4)$, pri čemu je, jednako kao i kod trajanja postupka (usporedi Graf 2.3), primjetan trend rasta.

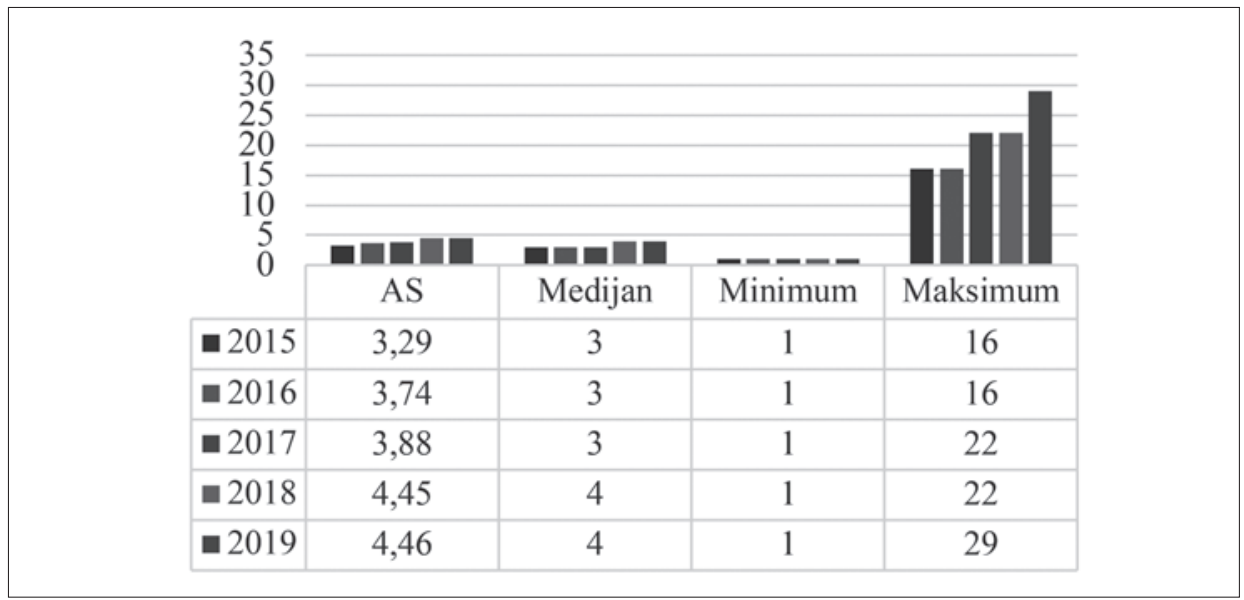

Graf 2.4 - Broj ročišta u postupcima riješenim kontradiktornom presudom po pojedinim godinama

U skupnom prikazu (Tablica 1.5) prosjek broja održanih ročišta u petogodišnjem razdoblju iznosio je nešto više od četiri ročišta iako je raspon ukupnog broja ročišta varirao od samo jednog do čak 29 ročišta. 
Tablica 1.5 - Broj ročišta u predmetima riješenim kontradiktornom presudom (skupni prikaz)

\begin{tabular}{|c|c|}
\hline $2015 .-2019$. & broj ročišta \\
\hline AS & 4,05 \\
\hline medijan & 4 \\
\hline minimum & 1 \\
\hline maksimum & 29 \\
\hline uzorak & 43473 \\
\hline
\end{tabular}

Kada povežemo broj ročišta s postotkom predmeta u kojima je takav broj ročišta održan, primjećujemo da je u više od 20 \% predmeta u 2015. i 2016. te od 35 do 40 \% predmeta u 2017., 2018. i 2019. održano pet ili više ročišta (Tablica 1.6). Ipak, u otprilike polovici predmeta održana su dva ili tri ročišta, s padom u posljednje dvije godine, što objašnjava i gore navedene medijane (usporedi Graf 2.4).

Tablica 1.6 - Odnos broja ročišta i postotka predmeta u postupcima riješenim kontradiktornom presudom

\begin{tabular}{|c|c|c|c|c|c|}
\hline & \multicolumn{5}{|c|}{ postotak predmeta } \\
\hline broj ročišta & $\mathbf{2 0 1 5}$ & $\mathbf{2 0 1 6}$ & $\mathbf{2 0 1 7}$ & $\mathbf{2 0 1 8}$ & $\mathbf{2 0 1 9}$ \\
\hline $\mathbf{1}$ & $3,44 \%$ & $0,54 \%$ & $0,56 \%$ & $0,55 \%$ & $1,51 \%$ \\
\hline 2 & $32,17 \%$ & $23,39 \%$ & $23,84 \%$ & $17,58 \%$ & $19,51 \%$ \\
\hline 3 & $28,81 \%$ & $28,28 \%$ & $26,74 \%$ & $22,04 \%$ & $21,59 \%$ \\
\hline 4 & $17,93 \%$ & $21,75 \%$ & $21,07 \%$ & $20,30 \%$ & $18,43 \%$ \\
\hline 5 & $9,44 \%$ & $13,09 \%$ & $11,84 \%$ & $14,17 \%$ & $13,33 \%$ \\
\hline$>6$ & $8,21 \%$ & $12,95 \%$ & $15,95 \%$ & $25,36 \%$ & $25,62 \%$ \\
\hline
\end{tabular}

\subsubsection{Analiza potencijalnih uzroka zatečenog stanja}

Prvi korak u analizi potencijalnih uzroka bio je provjeriti ovisi li zabilježeno prosječno trajanje postupka i broj održanih ročišta o veličini suda. Čini se da je odgovor negativan jer se među sudovima s iznadprosječnim trajanjem postupka, u smislu aritmetičke sredine i medijana (Tablica 1.7), nalaze i sudovi s većim brojem predmeta (Zagreb, Rijeka, Split), kao is manjim (Dubrovnik, Karlovac, Varaždin, Velika Gorica). 
Tablica 1.7 - Trajanje postupaka riješenih kontradiktornom presudom po pojedinim sudovima

\begin{tabular}{|l|c|c|c|c|c|}
\hline \multicolumn{1}{|c|}{ 2015. - 2019. } & AS & medijan & minimum & maksimum & uzorak \\
\hline Zagreb & 734 & $\mathbf{6 2 7}$ & 37 & 2453 & 8951 \\
\hline Bjelovar & 485 & 369 & 11 & 2373 & 1592 \\
\hline Čakovec & $\mathbf{6 2 3}$ & 560 & 71 & 2142 & 325 \\
\hline Dubrovnik & $\mathbf{6 3 8}$ & 492 & 42 & 2387 & 1454 \\
\hline Gospić & 539 & 421 & 19 & 2214 & 546 \\
\hline Karlovac & $\mathbf{6 3 0}$ & 546 & 38 & 2245 & 863 \\
\hline Koprivnica & 436 & 302 & 24 & 2163 & 696 \\
\hline Novi Zagreb & 711 & 616 & 24 & 2375 & 1353 \\
\hline Osijek & 408 & 285 & 20 & 2351 & 2419 \\
\hline Pula & 592 & 493 & 29 & 2337 & 2288 \\
\hline Požega & 568 & 453 & 38 & 2261 & 321 \\
\hline Rijeka & 660 & 549 & 33 & 2359 & 3334 \\
\hline Slavonski Brod & 592 & 494 & 14 & 2247 & 965 \\
\hline Šibenik & 437 & 301 & 13 & 2410 & 4668 \\
\hline Sisak & 549 & 420 & 4 & 2347 & 1407 \\
\hline Split & 659 & 541 & 26 & 2449 & 5367 \\
\hline Velika Gorica & $\mathbf{6 6 0}$ & 533 & 58 & 2195 & 409 \\
\hline Virovitica & 365 & 244 & 25 & 2205 & 812 \\
\hline Vukovar & 421 & 298 & 16 & 2287 & 1260 \\
\hline Varaždin & $\mathbf{6 4 0}$ & 502 & 24 & 2185 & 814 \\
\hline Zadar & 591 & 460 & 22 & 2414 & 3002 \\
\hline Zlatar & 516 & 413 & 48 & 2076 & 627 \\
\hline UKUPNO & 597 & 474 & 4 & 2453 & 43473 \\
\hline
\end{tabular}

Iako su u pravilu sudovi s duljim trajanjem postupka u pravilu zakazivali iznadprosječni broj ročišta (Zagreb, Rijeka, Split, Čakovec, Varaždin, Velika Gorica), to nije bio slučaj sa sudovima poput Koprivnice, Požege i Zadra koji su održavali velik broj ročišta unatoč ispodprosječnom trajanju postupka. Manji broj sudova koji su iznadprosječno dugo rješavali predmete (Dubrovnik, Novi Zagreb) održavali su ispodprosječan broj ročišta (Tablica 1.8). 
Tablica 1.8 - Broj ročišta u postupcima riješenim kontradiktornom presudom po pojedinim sudovima

\begin{tabular}{|l|c|c|c|c|c|}
\hline \multicolumn{1}{|c|}{ 2015. - 2019. } & AS & medijan & minimum & maksimum & uzorak \\
\hline Zagreb & 4.23 & 4 & 1 & 20 & 8951 \\
\hline Bjelovar & 4.01 & 4 & 1 & 15 & 1592 \\
\hline Čakovec & 4.16 & 4 & 1 & 11 & 325 \\
\hline Dubrovnik & 3.63 & 3 & 1 & 14 & 1454 \\
\hline Gospić & 3.56 & 3 & 2 & 13 & 546 \\
\hline Karlovac & 3.82 & 3 & 1 & 13 & 863 \\
\hline Koprivnica & 4.18 & 4 & 2 & 20 & 696 \\
\hline Novi Zagreb & 3.76 & 3 & 1 & 15 & 1353 \\
\hline Osijek & 3.74 & 3 & 1 & 20 & 2419 \\
\hline Pula & 3.82 & 3 & 1 & 15 & 2288 \\
\hline Požega & 4.36 & 4 & 2 & 12 & 321 \\
\hline Rijeka & 4.13 & 4 & 1 & 17 & 3334 \\
\hline Slavonski Brod & 3.96 & 4 & 1 & 15 & 965 \\
\hline Šibenik & 3.86 & 3 & 1 & 22 & 4668 \\
\hline Sisak & 3.51 & 3 & 1 & 29 & 1407 \\
\hline Split & 4.32 & 4 & 1 & 28 & 5367 \\
\hline Velika Gorica & 4.49 & 4 & 1 & 17 & 409 \\
\hline Virovitica & 3.19 & 3 & 1 & 11 & 812 \\
\hline Vukovar & 3.33 & 3 & 1 & 9 & 1260 \\
\hline Varaždin & 4.57 & 4 & 1 & 14 & 814 \\
\hline Zadar & 4.64 & 4 & 1 & 22 & 3002 \\
\hline Zlatar & 3.92 & 3 & 1 & 13 & 627 \\
\hline UKUPNO & 4.04 & 4 & 1 & 29 & 43473 \\
\hline
\end{tabular}

Podatak o opterećenosti sudaca (engl. Case per Judge) mogli smo promatrati samo u odnosu na 2016., 2017. i 2018. jer su to godine u kojima nije bilo reorganizacije pravosudne mreže. Kad smo u korelaciju doveli trajanje postupka i broj ročišta na pojedinom sudu s opterećenosti njegovih sudaca i savjetnika, primjećujemo da je ona u odnosu na broj ročišta zanemariva, dok je kod trajanja postupka bila slaba u 2016. i 2017. te gotovo nepostojeća u 2018. (Tablica 1.9). 
Tablica 1.9 - Korelacija opterećenosti sudaca s trajanjem postupka i brojem ročišta po pojedinim sudovima

\begin{tabular}{|l|c|c|c|}
\hline & 2016. & 2017. & 2018. \\
\hline trajanje postupka & 0.46 & 0.33 & 0.07 \\
\hline broj ročišta & 0.03 & 0.13 & 0.13 \\
\hline
\end{tabular}

U velikoj većini predmeta u eSpisu bila je naznačena vrijednost predmeta spora. Utvrdili smo da je u više od polovice predmeta, njih 54,56 \%, vrijednost predmeta iznosila između 10.000,01 i 50.000,00 kn, dok je u upola manje predmeta (njih 24,80\%) po vrijednosti bilo manje od 10.000,00 kn (Graf 2.5). Vrijednost predmeta spora u svakome predmetu mogli smo zatim pokušati staviti u međuodnos s trajanjem postupka i brojem ročišta. Utvrdili smo da postoji zanemariva do slaba korelacija između vrijednosti predmeta spora te trajanja postupka $\left(\mathrm{r}_{\mathrm{s}}=0,27\right)$ i broja ročišta zakazanih u postupku $\left(\mathrm{r}_{\mathrm{s}}=0,24\right)$. Drugim riječima, koliko god bila velika ili mala vrijednost predmeta spora, hrvatski sudovi će postupati na približno jednak način. Utvrđena je i slaba do umjerena korelacija između trajanja postupka i broja ročišta $\left(r_{s}=0,49\right)$, što znači da $u$ pravilu dulje trajanje postupka znači veći broj ročišta (i obrnuto).

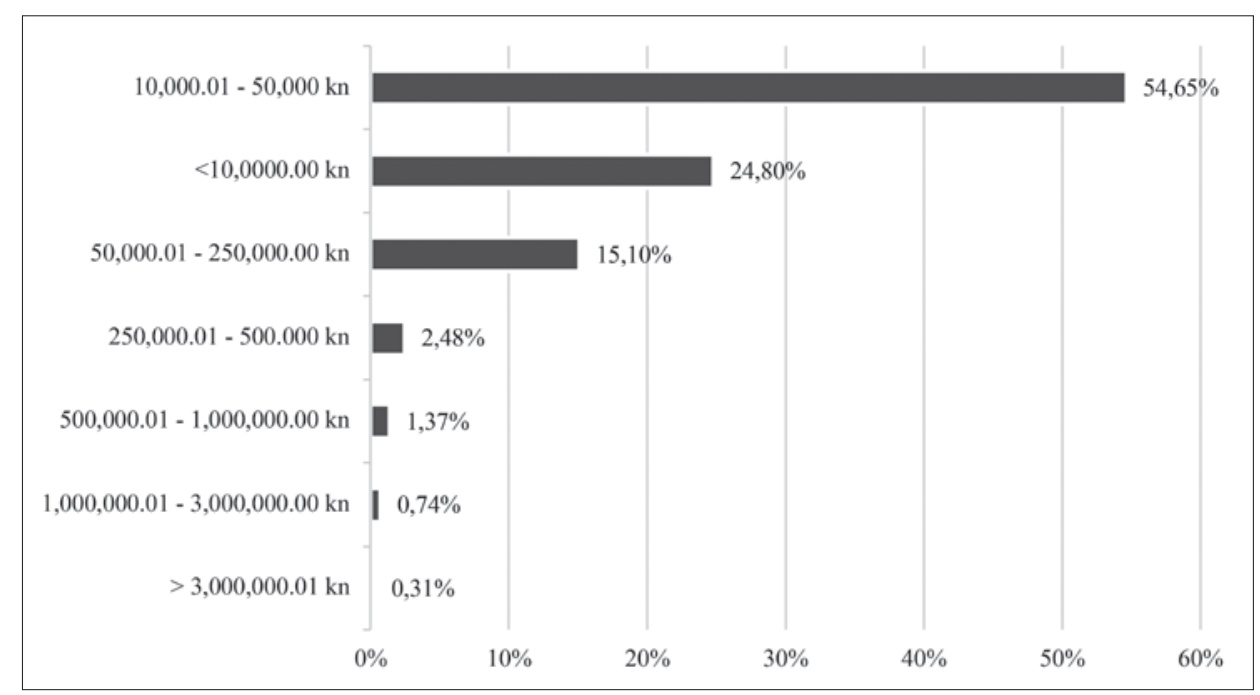

Graf 2.5 - Vrijednost predmeta spora u novim postupcima riješenim kontradiktornom presudom 
Daljnju korelaciju možemo pokušati utvrditi u odnosu na osobu koja je bila zadužena za vođenje postupka te činjenicu zastupanja jedne, obje ili nijedne stranke (Tablica 1.10). Utvrdili smo da je u postupku održavan otprilike jednak broj ročišta u promatranom razdoblju, neovisno o tome je li predmet vodio sudac ili sudski savjetnik, no postupak je trajao 14,24 \% dulje kad ga je provodio sudski savjetnik. Za razliku od toga, činjenica zastupanja pokazala se značajnom u slučaju manjeg broja slučajeva u kojima nijedna stranka nije bila zastupana jer su takvi postupci bili 35,34 \% kraći te je u njima održano 27,16 \% manje ročišta. Ako su obje stranke zastupane, što je najčešće slučaj, postupci su 17,08 \% dulji od prosjeka i u njima se održavalo 10,86 \% više ročišta. Manji broj ročišta održan je kad je bila zastupana samo jedna stranka ( $14,81 \%$ u slučaju tužitelja i $11,11 \%$ u slučaju tuženika), dok je trajanje postupka bilo kraće (26,13 \%) samo u onim predmetima u kojima je zastupan bio samo tužitelj.

Tablica 1.10 - Utjecaj ostalih čimbenika na trajanje postupka i broj ročišta

\begin{tabular}{|c|c|c|c|}
\hline $\begin{array}{c}\text { čimbenik/odnos } \\
\text { prema prosjeku }\end{array}$ & trajanje postupka & broj ročišta & postotak predmeta \\
\hline sudac & $-0,01 \%$ & $0,00 \%$ & $92,62 \%$ \\
\hline sudski savjetnik & $+11,91 \%$ & $-1,58 \%$ & $7,38 \%$ \\
\hline \multicolumn{3}{|c|}{} \\
\hline svi zastupani & $+17,08 \%$ & $+10,86 \%$ & $58,54 \%$ \\
\hline nitko zastupan & $-35,34 \%$ & $-27,16 \%$ & $31,74 \%$ \\
\hline samo tužitelj & $-26,13 \%$ & $-14,81 \%$ & $4,18 \%$ \\
\hline samo tuženik & $+0,16 \%$ & $-11,11 \%$ & $4,96 \%$ \\
\hline
\end{tabular}

\subsection{Istraživanje na uzorku predmeta Općinskog građanskog suda u Zagrebu}

\subsection{Trajanje postupka i broj ročišta u uzorku predmeta}

Trajanje postupka i broj ročišta u uzorku održavaju činjenicu da smo ih unaprijed ograničili na predmete u kojima su zakazana barem četiri ročišta, što implicira njihovo neučinkovito provođenje. Trajanje postupaka u uzorku bilo je iznadprosječno (usporedi Tablicu 1.3), približivši se prosječnom trajanju od dvije godine, a raspon je varirao od 140 do 1697 dana (Tablica 2.1). 
Tablica 2.1 - Trajanje postupaka u danima $(p<0,05)$

\begin{tabular}{|c|c|}
\hline & $\begin{array}{c}\text { trajanje } \\
\text { (u danima) }\end{array}$ \\
\hline AS & 712 \\
\hline medijan & 677 \\
\hline minimum & 140 \\
\hline maksimum & 1697 \\
\hline uzorak & 348 \\
\hline
\end{tabular}

Relativno najveći postotak predmeta u uzorku (30,46 \%) trajao je između dvije i tri godine. Velika većina predmeta $(89,65 \%)$ trajala je dulje od jedne godine, a u više od polovice predmeta $(68,4 \%)$ postupak je trajao najmanje 18 mjeseci. Svega 10,35 \% predmeta trajalo je manje od jedne godine (Tablica 2.2).

Tablica 2.2 - Trajanje postupaka u mjesecima $(p<0,05)$

\begin{tabular}{|c|c|}
\hline $\begin{array}{c}\text { trajanje } \\
\text { (u mjesecima) }\end{array}$ & postotak \\
\hline$>36$ & $13,51 \%$ \\
\hline $24-36$ & $30,46 \%$ \\
\hline $18-24$ & $24,43 \%$ \\
\hline $12-18$ & $21,26 \%$ \\
\hline $6-12$ & $9,20 \%$ \\
\hline $3-6$ & $1,15 \%$ \\
\hline
\end{tabular}

U uzorku je održan iznadprosječni broj ročišta (Tablica 2.3), što se jednako odnosi na aritmetičku sredinu $(x=5,09)$, tako i medijan $(m=5)$. Maksimalnih 13 održanih ročišta, s druge strane, manji je od maksimalnog broja održanih ročišta na svim sudovima (usporedi ukupne vrijednosti u Tablici 1.8).

Tablica 2.3 - Broj ročišta u postupku $(p<0,05)$

\begin{tabular}{|c|c|}
\hline ukupno & broj ročišta \\
\hline AS & 5.09 \\
\hline medijan & 5 \\
\hline minimum & 4 \\
\hline maksimum & 13 \\
\hline uzorak & 348 \\
\hline
\end{tabular}




\subsubsection{Postupanje u pojedinim stadijima prvostupanjskog parničnog postupka}

\subsubsection{Trajanje pojedinih stadija i broj ročišta u tim stadijima}

Što tiče trajanja pojedinih stadija (Tablica 2.4), najdugotrajnija je bila glavna rasprava u trajanju od nešto manje od godinu dana, počevši od zaključenja prethodnog postupka do (konačnog) zaključenja glavne rasprave. Približno jednako (samo tjedan dana manje) u prosjeku je trajao prethodni postupak (od podnošenja tužbe do zaključenja prethodnog postupka), dok je odlučivanje nakon zaključenja glavne rasprave trajalo oko mjesec dana.

Tablica 2.4 - Trajanje pojedinih stadija u postupku $(p<0,05)$

\begin{tabular}{|c|c|c|c|}
\hline & \multicolumn{3}{|c|}{ trajanje pojedinih stadija u danima } \\
\hline vrijednost & $\begin{array}{c}\text { prethodni } \\
\text { postupak }\end{array}$ & $\begin{array}{c}\text { stadij glavne } \\
\text { rasprave }\end{array}$ & $\begin{array}{c}\text { stadij } \\
\text { odlučivanja }\end{array}$ \\
\hline AS & 335 & 342 & 38 \\
\hline medijan & 275 & 303 & 35 \\
\hline minimum & 46 & 0 & 0 \\
\hline maksimum & 1335 & 1247 & 457 \\
\hline
\end{tabular}

Prosječan broj pripremnih ročišta $(\mathrm{x}=1,63)$ ispod je zakonskog maksimuma od dvaju pripremnih ročišta, ali je istodobno u uzorku zabilježen maksimalan broj od čak šest pripremnih ročišta (Tablica 2.6). U prosjeku je održano više od jednog ročišta za glavnu raspravu $(\mathrm{x}=2,57 ; \mathrm{m}=2)$. Prosjek broja ročišta za objavu samo je neznatno iznad jednog ročišta, što znači da je odgođeno u zanemarivom broju predmeta.

Tablica 2.5 - Broj ročišta u pojedinim stadijima $(p<0,05)$

\begin{tabular}{|c|c|c|c|}
\hline & $\begin{array}{c}\text { broj pripremnih } \\
\text { ročišta }\end{array}$ & $\begin{array}{c}\text { broj ročišta za } \\
\text { glavnu raspravu }\end{array}$ & $\begin{array}{c}\text { broj ročišta } \\
\text { za objavu }\end{array}$ \\
\hline AS & 1,63 & 2,57 & 1,02 \\
\hline medijan & 1 & 2 & 1 \\
\hline minimum & 1 & 1 & 1 \\
\hline maksimum & 6 & 9 & 3 \\
\hline
\end{tabular}

Promatrano u postotcima, u gotovo $60 \%$ predmeta održano je jedno pripremno ročište, u četvrtini predmeta dva, a u gotovo petini predmeta tri i više 
pripremnih ročišta. U relativno najvećem broju predmeta (42,53 \%) održana su tri ili više ročišta za glavnu raspravu, a samo u petini predmeta održano je jedno ročište za glavnu raspravu, od čega je u 52 predmeta (14,94 \%) ono održano neposredno nakon zaključenja prethodnog postupka. Samo u 2,01 \% predmeta zakazano je više od jednog ročišta za objavu (Tablica 2.7).

Tablica 2.6 - Postotak ročišta u pojedinim stadijima $(p<0,05)$

\begin{tabular}{|c|c|c|c|}
\hline broj ročišta & $\begin{array}{c}\text { pripremna } \\
\text { ročišta }\end{array}$ & $\begin{array}{c}\text { ročišta za glavnu } \\
\text { raspravu }\end{array}$ & $\begin{array}{c}\text { ročišta } \\
\text { za objavu }\end{array}$ \\
\hline $\mathbf{1}$ & $57,18 \%$ & $21,55 \%$ & $97,99 \%$ \\
\hline 2 & $25,29 \%$ & $35,92 \%$ & $1,72 \%$ \\
\hline 3 i više & $17,53 \%$ & $42,53 \%$ & $0,29 \%$ \\
\hline
\end{tabular}

2.3.2.2 Razmak između ročišta i sudskih radnji u prethodnom postupku

Prosječan razmak između ročišta iznosio je 124 dana, odnosno nešto više od četiri mjeseca. Najmanji utvrđeni razmak između ročišta iznosio je 23 dana, dok je najveći iznosio čak jednu godinu i dva mjeseca (Tablica 2.7).

Tablica 2.7 - Razmak između ročišta u danima $(p<0,05)$

\begin{tabular}{|c|c|}
\hline prvostupanjski postupak & razmak između ročišta \\
\hline AS & 124 \\
\hline medijan & 108 \\
\hline minimum & 23 \\
\hline maksimum & 439 \\
\hline uzorak & 348 \\
\hline
\end{tabular}

Kad je u pitanju razmak između drugih sudskih radnji u prethodnom postupku, poput slanja tužbe na odgovor i zakazivanja pripremnog ročišta, uočili smo razliku u postupanju sudova. Dok je veći dio sudaca i savjetnika istodobno sa slanjem tužbe na odgovor zakazivao pripremno ročište (njih 61,49\%), manji iako i dalje značajni dio sudaca i savjetnika (njih 39,51 \%) najprije je slao tužbu na odgovor da bi zatim, po primitku pisanog odgovora na tužbu, zakazivao pripremno ročište. U prvom slučaju za slanje tužbe na odgovor nakon njezina primitka i istodobno zakazivanje ročišta u prosjeku je trebalo 65 dana (Tablica 2.8). 
Tablica 2.8 - Razmak između sudskih radnji u slučaju istodobnog zakazivanja pripremnog ročišta $(p<0,05)$

\begin{tabular}{|c|c|}
\hline $\begin{array}{c}\text { istodobno zakazivanje } \\
\text { pripremnog ročišta }\end{array}$ & $\begin{array}{c}\text { razmak između tužbe i slanja na odgovor } \\
\text { (u danima) }\end{array}$ \\
\hline AS & 65 \\
\hline medijan & 28 \\
\hline minimum & 2 \\
\hline maksimum & 489 \\
\hline uzorak & 214 \\
\hline
\end{tabular}

Kad je pripremno ročište zakazivano sukcesivno, dakle tek nakon primitka pisanog odgovora na tužbu, tužba je više od dva tjedna ranije slana na odgovor, ali je pripremno ročište zakazivano nakon gotovo sedam mjeseci (Tablica 2.9).

Tablica 2.9 - Razmak između sudskih radnji u slučaju sukcesivnog zakazivanja pripremnog ročišta $(p<0,05)$

\begin{tabular}{|c|c|c|}
\hline $\begin{array}{c}\text { sukcesivno zakazivanje } \\
\text { pripremnog ročišta }\end{array}$ & $\begin{array}{c}\text { razmak između tužbe } \\
\text { i slanja na odgovor } \\
\text { (u danima) }\end{array}$ & $\begin{array}{c}\text { razmak između tužbe i } \\
\text { zakazivanja pripremnog ročišta } \\
\text { (u danima) }\end{array}$ \\
\hline AS & 39 & 208 \\
\hline medijan & 16 & 146 \\
\hline minimum & 2 & 13 \\
\hline maksimum & 508 & 1023 \\
\hline uzorak & 134 & 134 \\
\hline
\end{tabular}

\subsubsection{Analiza potencijalnih uzroka zatečenog stanja}

\subsubsection{Utjecaj pojedinih stadija na tijek postupka}

Dovođenje pojedinih stadija u korelaciju s trajanjem postupka i brojem ročišta (Tablica 2.10) slijedi podatke o njihovu trajanju jer su najdugotrajniji stadiji u kojima je održano najviše ročišta oni u odnosu na koje je utvrđena korelacija s trajanjem postupka i brojem ročišta (usporedi Tablicu 2.4). Utvrdili smo slabu do umjerenu korelaciju između prethodnog postupka i trajanja postup$\mathrm{ka}\left(\mathrm{r}_{\mathrm{s}}=0,46\right)$ te umjerenu između trajanja glavne rasprave i čitavog postupka $\left(r_{s}=0,59\right)$. Broj ročišta u slaboj je korelaciji jedino s trajanjem glavne rasprave $\left(r_{s}=0,33\right)$ te čitavog postupka $\left(r_{s}=0,36\right)$, dok je ona zanemariva u odnosu na trajanje prethodnog postupka i stadija odlučivanja. 
Tablica 2.10 - Korelacije trajanja pojedinih stadija i trajanja postupka

\begin{tabular}{|l|c|c|c|c|c|}
\hline & $\begin{array}{c}\text { trajanje } \\
\text { prethodnog } \\
\text { postupka }\end{array}$ & $\begin{array}{c}\text { trajanje } \\
\text { glavne } \\
\text { rasprave }\end{array}$ & $\begin{array}{c}\text { trajanje } \\
\text { stadija } \\
\text { odlučivanja }\end{array}$ & $\begin{array}{c}\text { trajanje } \\
\text { postupka }\end{array}$ & broj ročišta \\
\hline $\begin{array}{l}\text { trajanje } \\
\text { prethodnog } \\
\text { postupka }\end{array}$ & 1 & 1 & & & \\
\hline $\begin{array}{l}\text { trajanje } \\
\text { glavne } \\
\text { rasprave }\end{array}$ & $-0,30$ & 0,07 & 1 & & \\
\hline $\begin{array}{l}\text { trajanje } \\
\text { stadija } \\
\text { odlučivanja }\end{array}$ & 0,04 & 0,59 & 0,20 & 1 & \\
\hline $\begin{array}{l}\text { trajanje } \\
\text { postupka }\end{array}$ & 0,46 & 0,33 & 0,11 & 0,36 & 1 \\
\hline broj ročišta & 0,08 & & & & \\
\hline
\end{tabular}

Ranije opisana razlika u trenutku zakazivanja pripremnog ročišta odrazila se i na trajanje postupka i broj ročišta. Sukcesivno zakazivanje pripremnog ročišta u snažnoj je korelaciji s njegovim kasnijim održavanjem u tim postupcima $\left(\mathrm{r}_{\mathrm{s}}=0,85\right)$. U takvim je postupcima uočen bitno veći razmak između odgovora na tužbu i pripremnog ročišta (220 dana naprema 72 dana). ${ }^{27}$ Međutim, postupci u kojima je pripremno ročište zakazivano istodobno sa slanjem tužbe na odgovor u pravilu su trajali $9,39 \%$ dulje $\left(r_{s}=0,48\right)$, a pripremno ročište $u$ takvim je postupcima održano sto dana kasnije od prosjeka.

\subsubsection{Utjecaj parničnih radnji suda na tijek postupka}

Suci koji su provodili postupak u 75,86 \% predmeta postupak su vodili neznatno kraće i uz manje razmake od prosjeka, dok su sudski savjetnici postupke provodili uz neznatno dulje trajanje i iznadprosječne razmake između pojedinih radnji. Od potencijalno puno većeg utjecaja na tijek postupka bila je promjena suca ili savjetnika (tzv. presignacija) do koje je došlo u 13,51 \% slučajeva. Ti su predmeti trajali gotovo $20 \%$ dulje, uz iznadprosječne razmake između radnji i neznatno veći broj ročišta (Tablica 2.12).

27 Iz analize je isključeno 75 predmeta u kojima tuženik nije odgovorio na tužbu (bez donošenja presude zbog ogluhe), odnosno predmeti u kojima je tuženik svoj odgovor podnio tek nakon pripremnog ročišta. 
Tablica 2.12 - Utjecaj suda na tijek postupka $(p<0,05)$

\begin{tabular}{|c|c|c|c|c|}
\hline $\begin{array}{l}\text { čimbenik/odnos } \\
\text { prema prosjeku }\end{array}$ & $\begin{array}{c}\text { trajanje } \\
\text { postupka }\end{array}$ & broj ročišta & $\begin{array}{c}\text { razmak između } \\
\text { ročišta }\end{array}$ & uzorak \\
\hline sudac & $-2,11 \%$ & $+0,19 \%$ & $-4,03 \%$ & $75,86 \%$ \\
\hline sudski savjetnik & $+6,19 \%$ & $-0,79 \%$ & $+15,60 \%$ & $24,14 \%$ \\
\hline s presignacijom & $+19,46 \%$ & $+1,93 \%$ & $+13,89 \%$ & $13,51 \%$ \\
\hline bez presignacije & $-3,65 \%$ & $-0,39 \%$ & $-24,19 \%$ & $86,49 \%$ \\
\hline
\end{tabular}

Od sudskih radnji koje su bile od utjecaja na tijek postupka ističemo i odgodu ("prelaganje") ročišta sudskom odlukom (u pravilu) prije ili (iznimno) na sam dan održavanja ročišta, koju smo uočili u 133 predmeta u uzorku. ${ }^{28}$ Postupci u kojima je "preloženo" pripremno ročište u prosjeku su trajali 13,20 \% dulje od prosjeka. Ako je osim pripremnog bilo "preloženo" i ročište za glavnu raspravu, postupak je trajao 41,51 \% dulje od prosjeka. Postupci u kojima je "preloženo" isključivo ročište za glavnu raspravu trajali su 20,22 \% dulje od prosjeka, dok odgađanje ročišta za objavu nije bilo od značajnog utjecaja na tijek postupka (Tablica 2.13).

Tablica 2.13 - Trajanje postupka u predmetima u kojima je došlo do "prelaganja"

\begin{tabular}{|l|c|}
\hline \multicolumn{1}{|c|}{ vrsta "preloženog" ročišta } & trajanje postupka (u danima) \\
\hline pripremno ročište & 806 \\
\hline pripremno ročište i ročište za glavnu raspravu & 1005 \\
\hline ročište za glavnu raspravu & 755 \\
\hline ročište za objavu presude & 724 \\
\hline prosjek & 712 \\
\hline
\end{tabular}

Kad analiziramo razloge koji su doveli do "prelaganja" ročišta, primjećujemo da je do njega najčešće došlo iz razloga na strani raspravnog suca ili sudskog savjetnika s obzirom na to da je ono bilo razlog "prelaganja" 58,06 \% pripremnih ročišta te $51,00 \%$ ročišta za glavnu raspravu. Velik je broj ročišta i koja su "preložena" bez ikakvog obrazloženja u rješenju, što se osobito odnosi na ročišta za objavu koja su tako odgođena u 75,53 \% slučajeva, ali i pripremna ročišta

${ }_{28}$ U literaturi se "prelaganje" spominje kao pomicanje termina ročišta unaprijed (Dika, M., Građansko parnično pravo, Parnične radnje, V. knjiga, Narodne novine, Zagreb, 2008., str. 85). Na našem uzorku taj se pojam koristio i za pomicanje unatrag. 
$(29,03 \%)$ te u nešto manjoj mjeri na ročišta za glavnu raspravu $(22,92 \%)$. Ostali razlozi su uglavnom manje pojavnosti (Tablica 2.14, Tablica 2.15 i Tablica 2.16).

Tablica 2.14 - Razlozi “prelaganja” pripremnih ročišta

\begin{tabular}{|l|c|}
\hline \multicolumn{1}{|c|}{ razlog } & $\%$ \\
\hline bez obrazloženja & $29,03 \%$ \\
\hline bolest raspravnog suca/savjetnika & $29,03 \%$ \\
\hline spriječenost raspravnog suca/savjetnika & $29,03 \%$ \\
\hline neuredna dostava & $3,23 \%$ \\
\hline rješenje o mjesnoj nenadležnosti & $3,23 \%$ \\
\hline rok za postavljanje skrbnika & $3,23 \%$ \\
\hline pogrešan datum u pozivu & $3,23 \%$ \\
\hline
\end{tabular}

Tablica 2.15 - Razlozi “prelaganja” ročišta za glavnu raspravu

\begin{tabular}{|l|c|}
\hline \multicolumn{1}{|c|}{ razlog } & $\%$ \\
\hline spriječenost raspravnog suca/savjetnika & $35,42 \%$ \\
\hline bez obrazloženja & $22,92 \%$ \\
\hline bolest raspravnog suca/savjetnika & $14,58 \%$ \\
\hline spriječenost drugih sudionika & $12,50 \%$ \\
\hline spriječenost stranaka & $6,25 \%$ \\
\hline neuredna dostava & $4,17 \%$ \\
\hline presignacija & $2,08 \%$ \\
\hline dojava o bombi & $2,08 \%$ \\
\hline
\end{tabular}

Tablica 2.16 - Razlozi “prelaganja” ročišta za objavu

\begin{tabular}{|l|c|}
\hline \multicolumn{1}{|c|}{ razlog } & $\%$ \\
\hline bez obrazloženja & $73,53 \%$ \\
\hline ranije izrađena presuda & $8,82 \%$ \\
\hline bolest raspravnog suca/savjetnika & $8,82 \%$ \\
\hline spriječenost raspravnog suca/savjetnika & $5,88 \%$ \\
\hline preotvaranje glavne rasprave & $2,94 \%$ \\
\hline
\end{tabular}


2.3.3.3 Utjecaj parničnih radnji stranaka na tijek postupka

Broj stranaka (Tablica 2.17) bio je od zapaženijeg utjecaja na tijek postupka samo u rijetkim slučajevima kad je u postupku bilo više stranaka na aktivnoj i pasivnoj strani. ${ }^{29} \mathrm{Ti}$ su postupci trajali gotovo tri puta manje od prosjeka $(31,46 \%)$, s prosječno tri puta manjim razmakom između pojedinih radnji (36,29 \%). Kad je u pitanju broj ročišta, njihov najveći broj zabilježen je u postupcima s više tužitelja ( $9,75 \%$ više od prosjeka), a najmanji u postupcima u kojima je bilo više tuženika (6,45 \% manje od prosjeka).

Tablica 2.17 - Utjecaj broja stranaka na tijek postupka $(p<0,05)$

\begin{tabular}{|l|c|c|c|}
\hline $\begin{array}{c}\text { čimbenik/odnos } \\
\text { prema prosjeku }\end{array}$ & trajanje postupka & broj ročišta & $\begin{array}{c}\text { razmak između } \\
\text { ročišta }\end{array}$ \\
\hline više tužitelja & $-7,44 \%$ & $+9,75 \%$ & $-16,94 \%$ \\
\hline više tuženika & $-0,98 \%$ & $-6,45 \%$ & $+3,23 \%$ \\
\hline više tužitelja i tuženika & $-31,46 \%$ & $-1,77 \%$ & $-36,29 \%$ \\
\hline po jedna stranka & $+0,97 \%$ & $-0,76 \%$ & $+2,36 \%$ \\
\hline
\end{tabular}

Ispodprosječno trajanje postupka i razmak između sudskih radnji zabilježili smo u postupcima u kojima stranke uopće nisu bile zastupane dok je u slučaju obje zastupane stranke postupak trajao neznatno iznad prosjeka. U tim je slučajevima zakazano i 18,07 \% ročišta manje od prosjeka (Tablica 2.18).

Tablica 2.18 - Utjecaj zastupanja na tijek postupka $(p<0,05)$

\begin{tabular}{|l|c|c|c|}
\hline $\begin{array}{c}\text { čimbenik/odnos } \\
\text { prema prosjeku }\end{array}$ & trajanje postupka & broj ročišta & $\begin{array}{c}\text { razmak između } \\
\text { ročišta }\end{array}$ \\
\hline svi zastupani & $+1,79 \%$ & $+0,39 \%$ & $+3,88 \%$ \\
\hline jedna stranka zastupana & $-3,93 \%$ & $0,00 \%$ & $-9,68 \%$ \\
\hline nitko zastupan & $-12,78 \%$ & $-18,07 \%$ & $-3,23 \%$ \\
\hline
\end{tabular}

Stranke su se razmjerno često koristile zakonskom mogućnošću razmjene pisanih (pripremnih) podnesaka (tužitelj 3,59, a tuženik 1,62 po predmetu). U više od trećinu podnesaka stranaka pripremni podnesak koristio se radi očito-

29 U velikoj većini predmeta na svakoj je strani bila samo po jedna stranka $(81,61 \%)$. Više tuženika zabilježeno je u 14,37 \% predmeta, više tužitelja u 3,16 \%, a u 0,86 \% predmeta bilo je više osoba na obje strane. 
vanja na podnesak, na već izvedeni dokaz ili općenito tijek postupka. Podnesak je sredstvo i kojim su stranke sudu često dostavljale određene podatke ili obavijesti. Ostali podnesci služili su kao forma za stranačke dispozicije, prijedloge ili općenito komunikaciju sa sudom (Tablica 2.19 i Tablica 2.20).

Tablica 2.19 - Podnesci tužitelja $(p<0,05)$

\begin{tabular}{|l|c|}
\hline \multicolumn{1}{|c|}{ vrsta podneska tužitelja } & postotak \\
\hline očitovanje na podnesak, izvedeni dokaz ili tijek postupka & $34,40 \%$ \\
\hline dostava podataka ili obavijesti & $31,28 \%$ \\
\hline podnesak koji se odnosi na dokazni postupak & $12,75 \%$ \\
\hline požurnica & $6,66 \%$ \\
\hline dispozicije tužitelja & $5,13 \%$ \\
\hline procesni prijedlozi & $3,85 \%$ \\
\hline podnesci vezani uz zastupanje & $3,21 \%$ \\
\hline podnesci vezani uz upravljanje postupkom & $1,36 \%$ \\
\hline žalba ili upozorenje na procesnu povredu suda & $1,36 \%$ \\
\hline
\end{tabular}

Tablica 2.20 - Podnesci tuženika $(p<0,05)$

\begin{tabular}{|l|c|}
\hline \multicolumn{1}{|c|}{ vrsta podneska tuženika } & postotak \\
\hline očitovanje na podnesak, izvedeni dokaz ili tijek postupka & $44,66 \%$ \\
\hline dostava podataka ili obavijesti & $29,18 \%$ \\
\hline podnesak koji se odnosi na dokazni postupak & $9,61 \%$ \\
\hline podnesci vezani uz zastupanje & $5,34 \%$ \\
\hline procesni prijedlozi & $4,98 \%$ \\
\hline podnesci vezani uz upravljanje postupkom & $2,85 \%$ \\
\hline dispozicije tuženika & $1,42 \%$ \\
\hline žalba ili upozorenje na procesnu povredu & $1,25 \%$ \\
\hline požurnica & $0,71 \%$ \\
\hline
\end{tabular}

Stranke su u 15,52 \% predmeta nakon zaključenja prethodnog postupka pisanim podnescima dostavljale određene isprave ili predlagale nove dokaze (Tablica 2.21). Takvi su postupci trajali prosječno mjesec dana dulje. Postupak bi u prosjeku trajao dva mjeseca dulje ako bi stranka ili sud prigovorio takvom zakašnjelom podnošenju. Ako je sud odbio takav zakašnjeli prijedlog, postupak je bio ispodprosječnog trajanja $(x=690)$, dok je u slučaju prihvaćanja zakašnjelog dokaznog prijedloga nakon što je takvom zakašnjelom podnošenju prigovoreno postupak trajao više od deset mjeseci duže od prosjeka $(x=1037)$. 
Tablica 2.21 - Utjecaj novota na tijek postupka $(p<0,05)$

\begin{tabular}{|c|c|c|c|}
\hline $\begin{array}{c}\text { zakašnjelo dostavljen ili } \\
\text { predložen novi dokaz }\end{array}$ & trajanje postupka & broj ročišta & uzorak \\
\hline NE & 707 & 4,96 & $294(84,49 \%)$ \\
\hline DA & 743 & 5,77 & $54(15,51 \%)$ \\
\hline $\begin{array}{c}\text { u tim predmetima } \\
\text { prigovoreno zakašnjenju }\end{array}$ & trajanje postupka & broj ročišta & uzorak \\
\hline NE & 711 & 5,94 & $36(10,34 \%)$ \\
\hline DA & 805 & 5,44 & $18(5,17 \%)$ \\
\hline $\begin{array}{c}\text { ako jest, sud odbio } \\
\text { dokazni prijedlog }\end{array}$ & trajanje postupka & broj ročišta & uzorak \\
\hline DA & 690 & 5,00 & $12(3,45 \%)$ \\
\hline NE & 1037 & 6,33 & $6(1,72 \%)$ \\
\hline
\end{tabular}

Pripremni podnesci stranaka imali su značenje i u kontekstu odgoda ročišta. Nemogućnost stranke, odnosno njezina punomoćnika da se odmah izjasne na navode protivnika bio je drugi najčešći razlog odgode pripremnih ročišta u više od petinu slučajeva (22,69\%), dok je isti razlog dovodio do odgode ročišta za glavnu raspravu u $8,11 \%$ slučajeva. U slučaju pripremnih ročišta stranke su svojim izričitim ili prešutnim dispozicijama uzrokovale odgodu u više od polovine slučajeva (55,09 \%), dok je taj postotak bio nešto manji u slučaju ročišta za glavnu raspravu (39,64\%). U pripremnom stadiju osim stranaka glavni uzročnik odgoda bila je neuredna dostava, a u stadiju glavne rasprave odgodama su doprinijeli i drugi procesni subjekti (Tablica 2.22 i Tablica 2.23).

Tablica 2.22 - Razlozi odgode pripremnih ročišta $(p<0,05)$

\begin{tabular}{|l|c|}
\hline \multicolumn{1}{|c|}{ razlog odgode pripremnih ročišta } & postotak \\
\hline neuredna dostava tuženiku & $37,50 \%$ \\
\hline rok za očitovanje na podnesak ili konzultiranje sa strankom & $22,69 \%$ \\
\hline rok za dostavu podataka, isprava, punomoći ili za pribavljanje dokaza & $12,96 \%$ \\
\hline suglasni prijedlog za odgodu & $10,65 \%$ \\
\hline izostanak tuženika & $4,63 \%$ \\
\hline izostanak obje stranke & $1,85 \%$ \\
\hline dispozicije stranaka & $1,85 \%$ \\
\hline izostanak drugih procesnih sudionika (osim stranaka) & $0,93 \%$ \\
\hline izostanak tužitelja & $0,46 \%$ \\
\hline ostalo & $6,48 \%$ \\
\hline
\end{tabular}


Tablica 2.23 - Razlozi odgoda ročišta za glavnu raspravu osim radi dokazivanja $(p<0,05)$

\begin{tabular}{|l|c|}
\hline \multicolumn{1}{|c|}{ razlog odgode ročišta za glavnu raspravu } & postotak \\
\hline izostanak drugih procesnih sudionika & $26,13 \%$ \\
\hline neuredna dostava strankama & $10,21 \%$ \\
\hline nedolazak stranaka na ročište radi njihova saslušanja & $9,91 \%$ \\
\hline rok za dostavu podataka, isprava, punomoći ili za pribavljanje dokaza & $9,61 \%$ \\
\hline preotvaranje glavne rasprave & $9,61 \%$ \\
\hline rok za očitovanje na podnesak, nalaz ili izvedene dokaze & $8,11 \%$ \\
\hline suglasni prijedlog za odgodu & $7,21 \%$ \\
\hline dodatni rok za izvođenje dokaza & $4,80 \%$ \\
\hline donošenje procesne odluke & $3,30 \%$ \\
\hline rok za specifikaciju tužbenog zahtjeva ili ispravak tužbe & $2,70 \%$ \\
\hline neuredna dostava drugim procesnim sudionicima & $2,10 \%$ \\
\hline izostanak tuženika & $1,80 \%$ \\
\hline izostanak obje stranke & $0,30 \%$ \\
\hline ostalo & $4,20 \%$ \\
\hline
\end{tabular}

\subsubsection{Utjecaj ostalih čimbenika na tijek postupka}

Vrijednost predmeta spora u uzorku (Graf 3.1) uglavnom je slijedila omjere na općem uzorku (usporedi Graf 2.5) iako je samo 18,39 \% predmeta imalo vrijednost manju od 10.000,00 kuna.

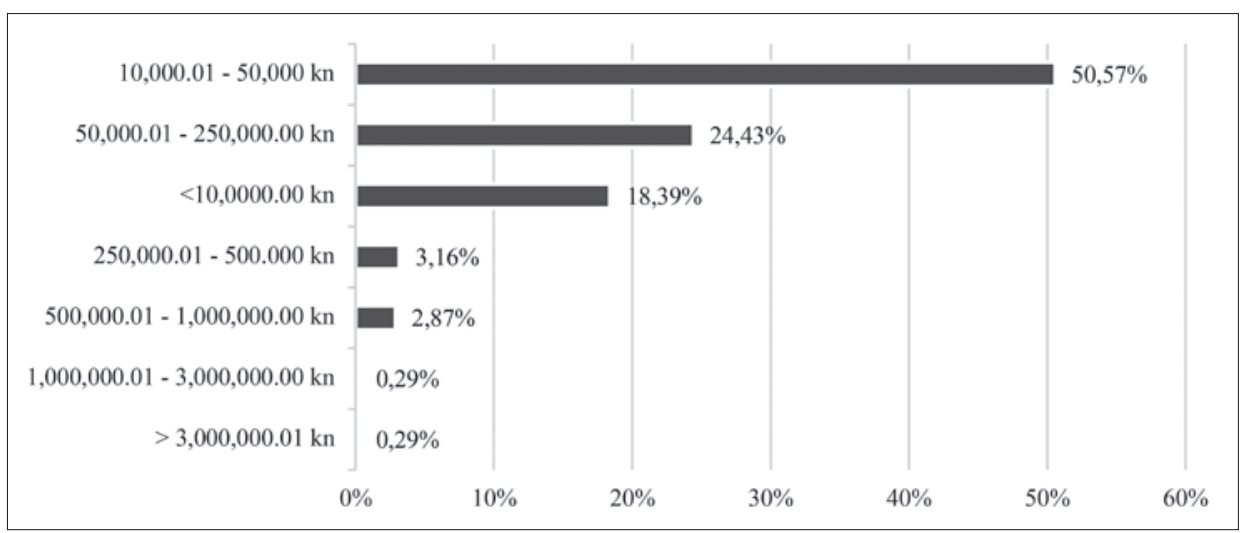

Graf 3.1 - Vrijednost predmeta spora u uzorku 
Vrijednost predmeta spora u zanemarivoj je korelaciji s brojem ročišta, dok je u odnosu na trajanje pojedinih stadija i čitavog postupka praktički nepostojeća (Tablica 2.24).

Tablica 2.24 - Korelacija vrijednosti predmeta spora i učinkovitosti postupka

\begin{tabular}{|l|c|c|c|c|c|}
\hline & $\begin{array}{c}\text { trajanje } \\
\text { prethodnog } \\
\text { postupka }\end{array}$ & $\begin{array}{c}\text { trajanje } \\
\text { glavne } \\
\text { rasprave }\end{array}$ & $\begin{array}{c}\text { trajanje } \\
\text { stadija } \\
\text { odlučivanja }\end{array}$ & $\begin{array}{c}\text { trajanje } \\
\text { postupka }\end{array}$ & broj ročišta \\
\hline $\begin{array}{l}\text { vrijednost } \\
\text { predmeta spora }\end{array}$ & 0,00 & $-0,06$ & 0,00 & $-0,02$ & $-0,16$ \\
\hline
\end{tabular}

U 28 predmeta $(8,05 \%)$ zabilježili smo preotvaranje glavne rasprave. U gotovo trećini slučajeva $(32,14 \%)$ glavna rasprava preotvarala se da bi stranke mogle dostaviti dodatnu dokumentaciju, a u četvrtini slučajeva $(25,00 \%)$ radi tzv. specifikacije tužbenog zahtjeva, odnosno njegova preciznog određenja ili sniženja (Graf 3.1). ${ }^{30} \mathrm{U}$ desetini slučajeva (10,72 \%) glavna se rasprava preotvarala radi provođenja vještačenja kao dokaznog prijedloga koji je sud ranije odbio ili radi dopune postupka, bez posebnog obrazloženja. Dispozicije stranaka, poput povlačenja tužbe ili priznanja tužbenog zahtjeva, bile su razlog 14,29 \% preotvaranja.

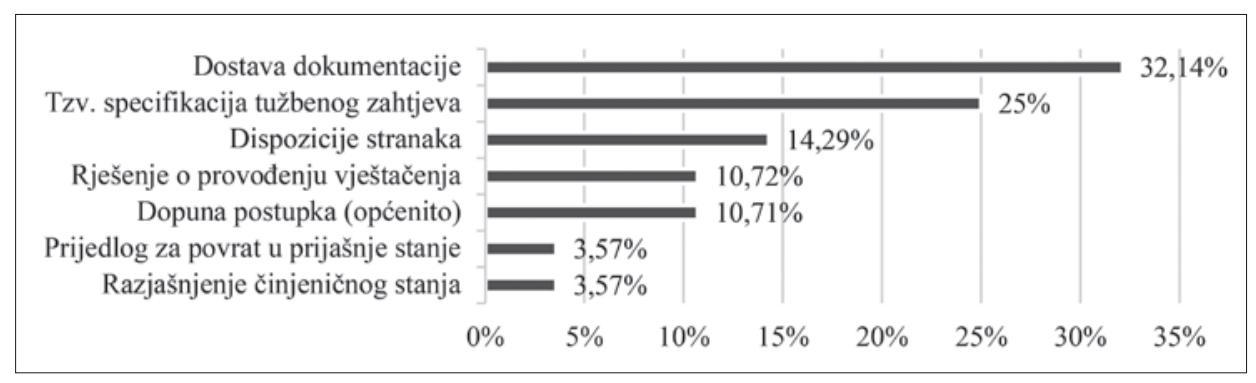

Graf 3.2 - Razlozi preotvaranja glavne rasprave $(p<0,05)$

Preotvaranje je u prosjeku postupak produljivalo više od šest mjeseci, računajući od donošenja rješenja o preotvaranju do donošenja i objave presude, iako raspon varira od mjesec dana do čak jedne godine i pet mjeseci (Tablica 2.25). Broj ročišta nakon preotvaranja varirao je od 1 do 3 , a u prosjeku je iznosio 1,68 ročišta $(m=2)$.

30 Sudski zapisnici govorili su o specifikaciji, a ne preinaci tužbenog zahtjeva iako za pozivanje na taj institut nema uporišta u ZPP-u. 
Tablica 2.25 - Utjecaj preotvaranja glavne rasprave na tijek postupka $(p<0,05)$

\begin{tabular}{|c|c|c|}
\hline & $\begin{array}{c}\text { produljenje postupka } \\
\text { (u danima) }\end{array}$ & $\begin{array}{c}\text { broj ročišta nakon } \\
\text { preotvaranja }\end{array}$ \\
\hline AS & 183 & 1,68 \\
\hline medijan & 124 & 2 \\
\hline minimum & 31 & 1 \\
\hline maksimum & 526 & 3 \\
\hline uzorak & 28 & 28 \\
\hline
\end{tabular}

U uzorku primjećujemo da je u 45,40 \% predmeta došlo do nekog problema s dostavom. Pritom su poteškoće s naknadnom dostavom strankama i drugim sudionicima (punomoćnicima, svjedocima, vještacima) bile češće od poteškoća u dostavi kojom se zasnivala litispendencija. Postupak je bio najbrže dovršen $(21,77 \%)$ uz najmanje ročišta (11,59\%) i s najmanjim razmakom između ročišta (30,65 \%) u predmetima u kojima su zabilježeni problemi s dostavom tužbe. $\mathrm{S}$ druge strane, u predmetima u kojima su zabilježeni problemi s naknadnom dostavom postupalo se neznatno sporije od prosjeka i uz veći broj ročišta. Predmeti s oba zabilježena problema trajali su približno prosjeku, ali je u njima zabilježen veći broj ročišta između kojih je zabilježen manji razmak (Tablica 2.26).

Tablica 2.26 - Utjecaj dostave na tijek postupka $(p<0,05)$

\begin{tabular}{|l|c|c|c|c|}
\hline $\begin{array}{c}\text { čimbenik/odnos } \\
\text { prema prosjeku }\end{array}$ & $\begin{array}{c}\text { trajanje } \\
\text { postupka }\end{array}$ & broj ročišta & $\begin{array}{c}\text { razmak između } \\
\text { ročišta }\end{array}$ & uzorak \\
\hline $\begin{array}{l}\text { problemi s dostavom } \\
\text { tužbe }\end{array}$ & $-21,77 \%$ & $-11,59 \%$ & $-30,65 \%$ & $6,90 \%$ \\
\hline $\begin{array}{l}\text { problemi u } \\
\text { naknadnoj dostavi }\end{array}$ & $+1,39 \%$ & $+3,60 \%$ & $-2,42 \%$ & $15,52 \%$ \\
\hline oba problema & $+0,97 \%$ & $+11,63 \%$ & $-12,10 \%$ & $22,99 \%$ \\
\hline bez problema & $+1,93 \%$ & $-3,93 \%$ & $+8,82 \%$ & $54,59 \%$ \\
\hline
\end{tabular}

\subsubsection{Usporedba rezultata s ranijim istraživanjima sličnog tipa}

Iako je svrha drugog dijela našeg empirijskog istraživanja bila pokušati pojedine radnje i propuste suda, stranaka i njihovih odvjetnika dovesti u vezu s mogućim uzrocima, bez donošenja općih zaključaka o brzini i načinu postupanja sudaca i savjetnika Općinskog građanskog suda u Zagrebu, korisno je rezultate našeg istraživanja usporediti s ranijim istraživanjima sličnog tipa koja su provedena na tom sudu. 
U istraživanju koje je pod okriljem Agencije za međunarodni razvoj Sjedinjenih Američkih Država (dalje u tekstu: USAID) na uzorku predmeta Općinskog građanskog suda u Zagrebu tijekom 2001. proveo američki Nacionalni centar za državne sudove (dalje u tekstu: NCSC), utvrđeno je da prvostupanjski parnični postupci u prosjeku traju 843 dana, s medijanom od 557 dana, da od podnošenja tužbe do prve sudske radnje protekne u prosjeku 75 dana, a do prvog ročišta za glavnu raspravu u prosjeku 172 dana. ${ }^{31}$ U prosjeku je zabilježeno 3,4 ročišta u predmetu (s maksimalnim brojem od 17 ročišta u jednom predmetu), a u predmetu su u prosjeku zabilježene 2,5 odgoda ročišta, koje su najvećim dijelom uzrokovane izostankom stranaka i svjedoka s ročišta (u 43 \% slučajeva), odnosno zakašnjelim podnošenjem dokaza i dokaznih prijedloga (u 33 \% slučajeva). ${ }^{32}$ Postupci su trajali 205 dana dulje od prosjeka ako je u okviru dokaznog postupka izvedeno vještačenje, a u tim je predmetima izrada pisanog nalaza i mišljenja trajala u prosjeku 158 dana. ${ }^{33}$

Usporede li se ove brojke s rezultatima drugog dijela našeg empirijskog istraživanja, važno je uočiti da naš uzorak odražava usporedive i gotovo jednake prakse koje su bile karakteristične za taj sud na početku ovog tisućljeća. Osim što je brzina postupanja usporediva, zabilježili smo slične uzročnike odgoda: izostanak stranaka i drugih sudionika, zakašnjele dokazne prijedloge i kašnjenja u provođenju dokaznog postupka. Imajući u vidu da se istraživanje iz 2001. koncentriralo na sve parnične predmete, za razliku od našeg istraživanja koje se koncentriralo na ograničen krug predmeta za koje smo unaprijed pretpostavili da je njihovo rješavanje bilo neučinkovito, ne možemo izvesti zaključak o mjeri u kojoj su te prakse prisutne i dalje na Općinskom građanskom sudu u Zagrebu, ali možemo sa sigurnošću potvrditi (ne)poduzimanje kojih parničnih radnji dovodi do neučinkovitih rezultata.

\section{KOJE JE TRENDOVE MOGUĆE UOČITI NA TEMELJU REZULTATA EMPIRIJSKOG ISTRAŽIVANJA?}

Analizom podataka iz sustava eSpis o postupanju općinskih sudova u redovnom parničnom postupku i sporovima male vrijednosti na uzorku od 246.997 predmeta koji su dovršeni od 2015. do 2019. dobiven je podatak o stvarnom trajanju tih postupaka, nasuprot podatcima o očekivanom trajanju postupka u

31 Functional Specifications Report for Computerization in Zagreb Municipal Court of The Republic of Croatia, NCSC, 2001., str. 14- 15.

32 Ibid., str. 16.

33 Ibid., str. 17. 
službenim izvješćima Ministarstva pravosuđa i Vrhovnog suda RH. U slučaju donošenja rješenja o odbačaju tužbe postupci su trajali u prosjeku dvije godine, odnosno više od dvije i pol godine u slučaju donošenja rješenja o apsolutnoj nenadležnosti. Za donošenje rješenja o relativnoj nenadležnosti trebalo je u prosjeku više od godinu dana. Do sudske nagodbe u postupcima je dolazilo nakon što je u postupku proteklo više od dvije godine i pol godine. Presude zbog ogluhe u prosjeku su se donosile nakon devet mjeseci, a presuda zbog izostanka u prosjeku nakon više od godinu i pol dana. Do dispozitivnih presuda $u$ prosjeku je dolazilo nakon godinu dana u slučaju presude na temelju priznanja, odnosno u prosjeku tri i pol godine u slučaju presude na temelju odricanja. Za donošenje kontradiktornih presuda u prosjeku je trebalo više od četiri godine.

S ciljem provjere teze o koncentraciji postupka nakon uvođenja prethodnog postupka, daljnje je istraživanje provedeno na uzorku 43.437 predmeta koji su pokrenuti isključivo za vrijeme važenja Novele iz 2013. te zatim u razdoblju između 2015. i 2019. dovršeni kontradiktornom presudom. Prosječno trajanje takvih postupaka po godinama varira od jedne godine i mjesec dana u 2015. do više od dvije godine i mjesec dana u 2019., pri čemu je ta brojka u stalnom porastu. Trend porasta primijećen je i kod broja održanih ročišta koji u promatranom razdoblju varira od prosječno 3,29 u 2015. do 4,46 ročišta u 2019.

U analizi potencijalnih uzroka takvog porasta utvrđeno je da prosječno trajanje postupka i broj održanih ročišta nisu ovisili o veličini suda, kao ni opterećenosti pojedinih njegovih sudaca i sudskih savjetnika. Utvrđeno je i da postoji zanemariva do slaba korelacija između vrijednosti predmeta spora te trajanja postupka i broja ročišta zakazanih u postupku. Utvrđena je i slaba do umjerena korelacija između trajanja postupka i broja ročišta. Za broj ročišta nije bila odlučna činjenica je li postupak provodio sudac ili sudski savjetnik, dok su postupci neznatno duže trajali u slučaju postupaka za koje su bili zaduženi sudski savjetnici. Postupci u kojima nijedna stranka nije bila zastupana bili su za trećinu kraći i u njima je održano gotovo trećinu manje ročišta. Postupci su bili neznatno dulji i u njima je održan neznatno veći broj ročišta ako su bile zastupane obje stranke. Manji broj ročišta održan je kad je bila zastupana samo jedna stranka, dok je trajanje postupka bilo kraće samo u onim predmetima u kojima je zastupan bio samo tužitelj.

Kad je u drugom dijelu našeg empirijskog istraživanja s općim podatcima o postupanju svih općinskih sudova uspoređen uzorak 348 predmeta Općinskog građanskog suda u Zagrebu upisnika P i Pn koji su pokrenuti nakon stupanja na snagu Novele iz 2013. i zatim dovršeni kontradiktornom presudom u 2015., 2016. i 2017., utvrđeno je da su postupci trajali iznadprosječno dugo - u prosjeku gotovo dvije godine, te je u njima održan iznadprosječan broj ročišta - njih u 
prosjeku 5,09. U analizi trajanja pojedinih stadija uočeno je da je najdugotrajniji stadij bio stadij glavne rasprave u trajanju od nešto manje od godinu dana, ali je približno jednako, odnosno samo tjedan dana manje, u prosjeku trajao prethodni postupak. Stadij odlučivanja u pravilu je trajao oko mjesec dana. U prosjeku je održano 1,63 pripremna ročišta, 2,57 ročišta za glavnu raspravu te 1,02 ročišta za objavu. Prosječan razmak između svih održanih ročišta u postupku iznosio je nešto više od četiri mjeseca. Razmak između slanja tužbe na odgovor i zakazivanja pripremnog ročišta ovisio je o tome je li sud istodobno sa slanjem tužbe na odgovor zakazivao pripremno ročište ili je to učinio tek po primitku pisanog odgovora na tužbu. U prvom slučaju, za slanje tužbe na odgovor nakon njezina primitka i istodobno zakazivanje ročišta u prosjeku je trebalo 65 dana. Kad je pripremno ročište zakazivano tek nakon primitka pisanog odgovora na tužbu, tužba je više od dva tjedna ranije slana na odgovor, ali je pripremno ročište zakazivano nakon gotovo sedam mjeseci.

U potrazi za potencijalnim uzrocima neučinkovitog postupanja u uzorku utvrđena je slaba do umjerena korelacija između prethodnog postupka i trajanja postupka te umjerena između trajanja glavne rasprave i čitavog postupka. Broj ročišta u slaboj je korelaciji s trajanjem glavne rasprave i trajanjem čitavog postupka. Uočeno je i da je postupak neznatno dulje trajao ako je pripremno ročište zakazano istodobno sa slanjem tužbe na pisani odgovor.

Usmjerivši svoju pozornost na parnične radnje i propuštanja suda, uočeno je da ni u ovom uzorku osoba zadužena za provođenje postupka nije bila odlučna za njegovo učinkovito provođenje. Uzorak je pokazao da su suci postupak vodili neznatno kraće i uz manje razmake od prosjeka, dok su sudski savjetnici postupke provodili uz neznatno dulje trajanje i iznadprosječne razmake između pojedinih radnji. Značajnija odstupanja utvrđena su tek u manjem broju predmeta u kojem je došlo do promjene te osobe (tzv. presignacije) jer su ti predmeti trajali gotovo $20 \%$ dulje, uz iznadprosječne razmake između radnji i neznatno veći broj ročišta. Postupci u kojima su suci i savjetnici odgodili ročišta uoči njihova održavanja ("prelaganje" ročišta) trajali su neznatno dulje, a utvrđeno je da su to pretežito činili zbog vlastite spriječenosti.

Postupci u kojima je bilo više stranaka na aktivnoj i pasivnoj strani trajali gotovo tri puta manje od prosjeka s prosječno tri puta manjim razmakom između pojedinih radnji. Kad je u pitanju broj ročišta, njihov najveći broj zabilježen je u postupcima s više tužitelja, a najmanji u postupcima u kojima je bilo više tuženika. Ispodprosječno trajanje postupka i razmak između sudskih radnji zabilježili smo u postupcima u kojima stranke uopće nisu bile zastupane, dok je u slučaju obje zastupane stranke postupak trajao neznatno iznad prosjeka, ali uz gotovo 20 \% ročišta manje od prosjeka. Stranke su se razmjerno često koristile 
zakonskom mogućnošću razmjene pisanih (pripremnih) podnesaka (tužitelj 3,59, a tuženik 1,62 po predmetu). U više od trećinu podnesaka stranaka pripremni podnesak koristio se radi očitovanja na podnesak, na već izvedeni dokaz ili općenito tijek postupka. Nemogućnost stranke, odnosno njezina punomoćnika da se odmah izjasne na navode protivnika u takvim podnescima bio je drugi najčešći razlog odgode pripremnih ročišta u više od petinu slučajeva, dok je isti razlog dovodio do odgode ročišta za glavnu raspravu u znatno manjem broju predmeta. Uočeno je da su stranke u 15,52 \% predmeta nakon zaključenja prethodnog postupka pisanim podnescima dostavljale određene isprave ili predlagale nove dokaze, što bi u prosjeku produljivalo postupak dva mjeseca dulje ako bi stranka ili sud prigovorili takvom zakašnjelom podnošenju, odnosno više od deset mjeseci ako je sud prihvatio takve zakašnjele prijedloge.

U analizi ostalih čimbenika uočeno je da je u uzorku vrijednost predmeta spora u zanemarivoj korelaciji s trajanjem postupka i brojem ročišta. U manjem je broju predmeta uočeno i preotvaranje glavne rasprave koje je u prosjeku postupak produljivalo više od šest mjeseci, dok je broj ročišta nakon preotvaranja u prosjeku iznosio 1,68 ročišta. U gotovo polovici predmeta došlo je do nekog oblika problema s provođenjem dostave. Postupci u kojima je uočen problem sa zasnivanjem litispendencije trajali su zamjetno kraće, uz manje ročišta i manji razmak između ročišta. Postupci u kojima su se javili naknadni problemi u provođenju dostave trajali su neznatno dulje i uz neznatno veći broj ročišta. Predmeti u kojima su uočena oba problema trajali su približno prosjeku, ali je u njima zabilježen veći broj ročišta između kojih je zabilježen manji razmak.

Smatramo da je naše empirijsko istraživanje dokazalo da hrvatski parnični postupak nije postao koncentriraniji i brži uvođenjem prethodnog postupka. Postupci dovršeni kontradiktornom presudom traju sve dulje i u njima se zakazuje sve veći broj ročišta, pri čemu trajanje i broj ročišta ne ovise ni o veličini suda ni o opterećenosti njegovih sudaca. Na ciljanom je reprezentativnom uzorku naše empirijsko istraživanje pokazalo da je uzrok neučinkovitom postupanju kombinacija parničnih radnji suda i stranaka, a tek u manjoj mjeri drugi čimbenici poput dostave ili presignacije predmeta, dok ono ne ovisi o vrijednosti predmeta spora.

\section{UMJESTO ZAKLJUČKA: KAKO BI PRETHODNI POSTUPAK TREBALO PRILAGODITI DA BI ON ODGOVARAO NAJBOLJIM KOMPARATIVNIM PRAKSAMA?}

Iako je na temelju rezultata našeg empirijskog istraživanja odgovor na pitanje postavljeno u naslovu našeg rada očito negativan jer smo uočili sve veći 
broj ročišta i sve dulje trajanje postupka od kada je u njega uveden prethodni postupak, u donošenju odluke o poželjnom smjeru razvoja prethodnog postupka bilo bi pogubno zaključiti kako je on sam po sebi loša pojava te da bi ga trebalo ukloniti iz ZPP-a. Naprotiv, najbolje komparativne prakse pokazuju da pripremni stadij igra ključnu ulogu u učinkovitom provođenju parničnog postupka ${ }^{34}$, što znači da je potrebna njegova prilagodba, a ne uklanjanje.

Početna točka bilo koje procesne reforme je svijest da pravosuđe predstavlja javnu uslugu ${ }^{35}$ koja je do sada u Hrvatskoj, čini se, izostala. ${ }^{36}$ Naime, ako pravosuđe predstavlja javnu uslugu, načelno bi trebalo svima pod jednakim uvjetima omogućiti pristup toj javnoj usluzi. Međutim, ograničenost resursa u obliku novca i vremena onemogućuje da se svakom predmetu posveti jednaka pažnja. Zbog toga je u praksi potrebna primjena procesne razmjernosti, odnosno nastojanja da se postupanje u svakom pojedinom predmetu prilagodi njegovim osobitostima, odnosno činjeničnoj i pravnoj složenosti predmeta, njegovoj vrijednosti, važnosti za stranke te društvo u cjelini. ${ }^{37}$

Takvu promjenu paradigme, doduše, samo je djelomično moguće postići zakonodavnim intervencijama. Vrijeme je da se znanstvena i stručna javnost

34 Nylund, A., Introduction to the Preparatory Stage of Civil Proceedings, u: Ervo, L.; Nylund, A. (ur.), Current Trends in Preparatory Proceedings. A Comparative Study of Nordic and Former Communist Countries, Dordrecht, Heidelberg, New York, London, Springer, 2014., str. 8; Kramer, X. E., The Structure of Civil Proceedings and Why It Matters: Exploratory Observations on Future ELI-UNIDROIT European Rules of Civil Procedure, Uniform Law Review, vol. 19, br. 2, 2014., str. 225 - 226. Vidi i Načelo br. 1(1) Preporuke br. R(84)5, ALI/UNIDROIT Načelo transnacionalnog građanskog postupka br. 9, ALI/UNIDROIT Pravila transnacionalnog građanskog postupka br. 12 - 14 i 18 - 23 te ELI/UNIDROIT Transnacionalna pravila građanskog postupka br. $23-24$ i $61-63$.

35 Storme, M., A Single Civil Procedure for Europe: A Cathedral Builders' Dream, Ritsumeikan Law Review, International Edition, 2005., str. 98; Zuckerman, A. A. S., Court Adjudication of Civil Disputes: A Public Service to be Delivered With Proportionate Resources, Within a Reasonable Time and at Reasonable Cost, u: van Rhee, C. H.; Heirbaut, D.; Storme, M. (ur.), The French Code of civil procedure (1806) after 200 years, The civil procedure tradition in France and abroad, Kluwer, Mechelen, 2008., str. 435 - 436; Ervo, L., Changing Civil Proceedings - Courts Service or State Economy, u: Carpi, F. et al., Recent trends in economy and efficiency of civil procedure: materials of international conference, Vilnius University, Vilnius, 2013., str. 56 - 57.

36 Bratković, op. cit. u bilj. 4, str. 177.

37 Hodges, C., The Europeanisation of Civil Justice: Trends and Issues, Civil Justice Quarterly, vol. 26, 2007., str. 98; García Odgers, R., El Case Management en perspectiva comparada. Teoría, evolución histórica, modelos comparados y un caso en desarrollo, Tirant lo Blanch, Valencia, 2020., str. 225. 
oslobodi hrvatske inačice "mita o reformi"38, odnosno nastojanja da svaku društvenu situaciju pokuša razriješiti novim propisom. U situaciji ubrzanih društvenih promjena te sve veće kompleksnosti i brojnosti društvenih odnosa ne može se više očekivati da će izmjena propisa sama po sebi postići željeni učinak, ako je to uopće ikad i bilo razumno očekivati. Zakonodavna aktivnost trebala bi se ograničiti na propisivanje ciljeva i okvira djelovanja u postupku, koji mogu imati trajniju vrijednost, dok bi odluka u svakom pojedinom predmetu trebala ovisiti o sudskoj ocjeni konkretnih okolnosti. ${ }^{39}$ Ovaj je problem u Hrvatskoj ipak dublji i složeniji, za što postoje povijesni, ideološki, ali i nomotehnički razlozi.

Dokle god je u očima sudaca, ali i drugih pravnih profesionalaca, sud dužan pravilno i potpuno utvrditi činjenično stanje ma od kakvog god utjecaja to bilo na trajanje i troškove postupka, kao što je to prema shvaćanju u literaturi i (možda više) judikaturi bio dužan prije Novele ZPP-a iz 2003. ${ }^{40}$, ekonomičnost i brzina postupanja ne predstavljaju varijable prilikom donošenja odluka o upravljanju postupkom. Takav jednodimenzionalan pogled na parnični postupak ${ }^{41}$ objašnjava i otpor uvođenju bilo kakvih ograničenja prava stranaka u obliku procesnih prekluzija ${ }^{42}$, što također ne doprinosi pravnoj kulturi koja njeguje brz

38 Spominjemo hrvatsku inačicu jer pojam u oprečnom smislu koristi Leubsforf u: Leubsdorf, J., The Myth of Civil Procedure Reform, u: Zuckerman, A. A. S. (ur.), Civil Justice in Crisis: Comparative Perspectives of Civil Procedure, Oxford University Press, Oxford, 1999., str. 53.

39 Verkerk, R. R., What is Judicial Case Management, u: van Rhee, C. H. (ur.), Judicial Case Management and Efficiency in Civil Litigation, Intersentia, Antwerp, Oxford, Portland, 2008., str. 44 - 46; vidi i van Rhee, C. H.; Fu, Y., The Role of the Judge and the Parties in Civil Litigation in China and Europe: An Introduction, u: van Rhee, C. H.; Fu, Y. (ur.), Civil Litigation in China and Europe. Essays on the Role of the Judge and the Parties, Springer, Dordrecht, Heidelberg, New York, London, 2014., str. 1. Iz tog se razloga protivimo nastojanjima da se unaprijed propiše trajanje pojedinih stadija ili čak i čitavog postupka.

40 Uzelac, A., Croatia: Omnipotent Judges as the Cause of Procedural Inefficiency and Impotence, u: van Rhee, C. H.; Fu, Y. (ur.), Civil Litigation in China and Europe. Essays on the Role of the Judge and the Parties, Springer, Dordrecht, Heidelberg, New York, London, 2014., str. 198; Dika, M.; Uzelac, A., Zum Problem des richterlichen Aktivismus in Jugoslawien, Zbornik Pravnog fakulteta u Zagrebu, vol. 40, br. 4, 1990., str. 397 i 400.

41 Nasuprot trodimenzionalnom konceptu pravosuđa koji je predstavio Zuckerman i koji osim zakonitosti i pravilnosti sudskih odluka uzima u obzir vrijeme i troškove postupka. Zuckerman, A. A. S., Civil Justice in Crisis: Comparative Dimensions of Civil Procedure, u: Zuckerman, A. A. S. (ur.), Civil Justice in Crisis: Comparative Perspectives of Civil Procedure, Oxford University Press, Oxford, 1999.

42 Za primjer relativno blage kritike u tom smjeru u stručnoj literaturi vidi npr. Bugarin, B., Osvrt na Novelu Zakona o parničnom postupku iz 2008., Hrvatska pravna 
i jeftin pristup pravosuđu. Sadržajna i vremenska ograničenja, naime, pogrešno je smatrati ograničenjem prava na pristup pravosuđu jer ona predstavljaju metodu ostvarenja prava na pristup pravosuđu na protivnoj strani, ali i od strane svih ostalih korisnika pravosuđa kao javne usluge. ${ }^{43}$ Možda razloge zbog kojih su neke od ovih poruka ostale relativno nezamijećene u literaturi treba tražiti i u činjenici da je članak 10. ZPP-a, u kojem je proklamirano načelo ekonomičnosti, opterećen mnogobrojnim tehničko-administrativnim odredbama o ovrsi na temelju rješenja o pristojbi. ${ }^{44}$

Zbog promašene nomotehnike, ali i pogrešnog shvaćanja jačanja raspravnih (akuzatornih) elemenata u parničnom postupku nakon Novele ZPP-a iz 2003. ${ }^{45}$ ispod radara sudaca i drugih pravnih profesionalaca ostala je i izuzetno važna izmjena do koje je došlo Novelom ZPP-a iz 2019. prema kojoj više nije samo sud odgovoran za suđenje u razumnom roku i uz razumne troškove, već za to odgovornost dijele i stranke i drugi sudionici u postupku. ${ }^{46}$ Ranije implicirano, a sada izričito proklamirano načelo lojalne suradnje karakteristika je modernih parničnih postupaka. To načelo ima dvostruke implikacije koje nastoje naći

revija, prosinac 2008., str. 99 - 100; Šagovac, A., Prekluzije sa zaključenjem prethodnog postupka, Informator, vol. 63, br. 6388, 19. listopada 2015., str. 12 - 13.

43 Bentham, J.; Letter V: On the Bill Called Lord Eldon's, u: Bowring, J. (ur.), The Works of Jeremy Bentham, vol. 5, William Tait, Edinburgh, 1843., str. 47; Zuckerman, A. A. S., On Civil Procedure: Principles of Practice, 3. izdanje, Sweet and Maxwell, London, 2013., str. 12 - 13.

44 Nedostatka je svjesna i stručna javnost. Vidi Bugarin, op. cit. u bilj. 42, str. 2; Zrilić, Z., Prethodni postupak prema Nacrtu prijedloga Zakona o izmjenama i dopunama Zakona o parničnom postupku, Informator, vol. 56, br. 5661, 7. lipnja 2008., str. 3.

45 U stručnoj literaturi govori se o traženju "stranačke" ili "formalne" istine nasuprot materijalnoj (tako npr. Zrilić, Z., Načelo otvorenog pravosuđenja u svjetlu predloženih izmjena i dopuna Zakona o parničnom postupku, Hrvatska pravna revija, siječanj 2003., str. 8; Pavlović, M., Utvrđivanje stranačke istine u parničnom postupku s posebnim osvrtom na primjenu načela otvorenog pravosuđenja, Hrvatska pravna revija, ožujak, 2004., str. 84; Abramović, A., Poželjna mjera utjecaja suda u odnosu na dokazivanje i neke druge parnične radnje stranaka, Hrvatska pravna revija, lipanj 2005., str. 91). Nije Novelom ZPP-a iz 2003. došlo do promjene kvalitete istine koja se traži jer sud i dalje nije vezan zakonskim dokaznim pravilima. Došlo je jedino do promjene inicijative za utvrđivanje činjenica i izvođenje dokaza koja u pravilu može biti samo na strankama. Čak je pretjerano reći i da je 2003. napuštena inkvizitorna maksima, s obzirom na brojne inkvizitorne elemente u postupku. Tako sud odlučuje koji će se dokazi izvesti, u pravilu pribavlja te dokaze i izvodi ih. U odnosu na pravila iskustva i pravna pravila (iura novit curia) kao sastavne dijelove procesnog materijala odgovornost je također primarno na sudu, a podredno na strankama.

46 Novi čl. 10. st. 1. ZPP-a. 
odgovarajući balans između povijesnih oblika postupaka koji su stavljali preveliki naglasak na inicijativu suda, odnosno stranaka. ${ }^{47} \mathrm{~S}$ jedne strane, sud svoje

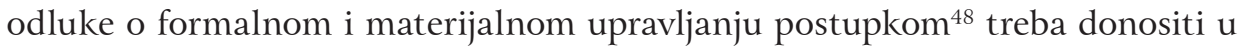
dijalogu sa strankama, bez naznaka paternalizma. ${ }^{49}$ Stranke, s druge strane, trebaju imati ne samo terete, već i prave procesne dužnosti jer bez njihova izvršavanja nije moguće ostvariti cilj razmjerno brzog i učinkovitog postupka. ${ }^{50}$ Danas je jasno da se optimalan rezultat u parnici može ostvariti samo dijalogom suda i stranaka te podjelom odgovornosti i zadaća, a ne stavljanjem naglaska na inicijativu samo jednog od njih. ${ }^{51}$

Čak i kad razmotrimo diskrecijska ovlaštenja suda koja već postoje u našem procesnom zakonodavstvu, naši empirijski podatci dokazuju da se ona ne koriste na odgovarajući način. ${ }^{52}$ Njihovu listu bi možda i trebalo proširiti, no bez odgovarajuće primjene tih ovlaštenja, koja bi uzela u obzir njihovu osnovnu svrhu, nije moguće očekivati optimalne rezultate. Najlakše bi bilo svaliti odgovornost na sud i zaključiti da je nestručnost ili nesavjesnost sudaca glavni uzročnik ovih problema. No, naše empirijsko istraživanje također pokazuje da stranke, odnosno njihovi odvjetnici koji u velikoj većini predmeta zastupaju barem jednu stranku, svojim radnjama i propustima često uzrokuju odgode ročišta, nekad iz posve neopravdanih razloga, a nekad i naizgled opravdano, ali sa značajnim učinkom

47 ELI/UNIDROIT Transnacionalno pravilo građanskog postupka br. 2, kom. 1.

48 Formalno upravljanje postupkom odnosi se na donošenje odluka o rokovima, ročištima i formi postupanja, dok se materijalno upravljanje postupkom odnosi na odluke koje su od utjecaja na odluku o meritumu ili prikupljanje procesnog materijala. Fasching, H. W., Lehrbuch des österreichischen Zivilprozeßrechts, 2. Aufl., Manzsche Verlag, Beč, 1990., str. 412 - 413; Rechberger, W. H., Zivilprozessrecht, 8. izd., Manz, Beč, 2010., str. 336 (nešto drukčije vidi Triva, S.; Dika, M., Građansko parnično procesno pravo, Narodne novine, Zagreb, 2004., str. 354).

49 Stürner, R., Parteiherrschaft versus Richtermacht - Materielle Prozessleitung und Sachverhaltsaufklärung im Spannungsfeld zwischen Verhandlungsmaxime und Effizienz, Zeitschrift für Zivilprozess, vol. 123, br. 2, 2010., str. 154.

50 Ibid., str. 156 - 157. Vidi i ELI/UNIDROIT Transnacionalno pravilo građanskog postupka br. 2, kom. 7 .

51 Nylund, op. cit. u bilj. 34, str. 10; Waxse, D. J., Cooperation - What Is It and Why Do It?, Richmond Journal of Law \& Technology, vol. XVIII, br. 3, 2012., str. 18.

52 Naše je empirijsko istraživanje pokazalo mehanički pristup primjeni procesnih pravila umjesto njihove prilagodbe osobitostima svakog pojedinog predmeta. To potvrđuje i podatak da u parničnim predmetima na općinskim sudovima ne postoji korelacija između vrijednosti predmeta spora te trajanja postupka i broja ročišta. 
na tijek postupka. ${ }^{53}$ Ovi rezultati potvrđuju kako bi ključni pravnopolitički cilj procesne reforme trebalo prije svega biti dodatno naglašavanje koncepta podijeljene odgovornosti kako bi je u konačnici internalizirali sudovi, stranke i odvjetnici kao najvažniji procesni subjekti.

Sve ranije izrečeno ne znači da je sam zakonodavni okvir trenutačno, u kontekstu prethodnog postupka, optimalan i da odgovara najboljim europskim i svjetskim praksama. O njima smo govorili drugdje, stoga sad nećemo detaljno navoditi rješenja karakteristična za pravne poretke koje bismo mogli smatrati uzorom $^{54}$, odnosno za međunarodne standarde i smjernice među kojima za naš postupak najznačajnije mjesto imaju nedavno donesena ELI/UNIDROIT Transnacionalna pravila građanskog postupka. ${ }^{55}$ Umjesto toga, u obliku sažetka, u nastavku dajemo najvažnije prijedloge u odnosu na pravila o prethodnom postupku koja bi trebalo korigirati u nekoj od sljedećih novela ZPP-a.

\section{a) Struktura prethodnog postupka}

Za razliku od tužbe i odgovora na tužbu koji predstavljaju pisanu podlogu za kasniji razvoj procesnih aktivnosti u postupku, jer se njima određuju predmet spora i predmet raspravljanja, daljnja razjašnjenja i dopune koja su potrebna mogu se poduzeti i u pisanom podnesku i na pripremnom ročištu. Ta je forma komplementarna, pa o okolnostima svakog pojedinog slučaja ovisi bi li bilo dovoljno da sud pojedina razjašnjenja zatraži u pisanom obliku uoči ročišta ili tek na pripremnom ročištu, na kojem je moguća brža i neposrednija komunikacija.

U svjetlu najboljih komparativnih praksi, sud ne bi trebao biti obvezan u svim predmetima, pa čak i u sporovima zanemarive složenosti, vrijednosti i važnosti, zakazati pripremno ročište. ${ }^{56}$ Ovlaštenje koje je uvedeno Novelom

53 Odgode zbog uručenja podnesaka na ročištu ili prekasno uoči ročišta primjer su neopravdanih razloga. Naizgled opravdan razlog, ali koji dovodi do odugovlačenja, postoji u slučaju odgoda radi pokušaja mirnog rješenja spora, dakle kad postoje alternativna, bolja sredstva za postizanje te svrhe u okviru postojećih procesnih pravila (čl. 186.d - 186.g ZPP-a).

54 Detaljni prikaz engleskog, njemačkog i slovenskog postupka nalazi se u: Brozović, J., Priprema i organizacija raspravljanja u parničnom postupku, doktorska disertacija, Pravni fakultet, Zagreb, 2021., str. 90 - 190.

55 Pravila su dostupna na engleskom i francuskom jeziku na mrežnim stranicama UNIDROIT: https://www.unidroit.org/instruments/civil-procedure/eli-unidroit-rules/ (16. prosinca 2021.).

56 Sporovi male vrijednosti trebali bi biti brzi i jednostavni postupci u kojima se održava jedno ročište za usmenu raspravu i izvode svi dokazi (tako ranije i Klein, F., 
ZPP-a iz 2019. da sud u određenom roku traži od stranaka pisano izjašnjenje o određenim okolnostima, kako uoči pripremnog ročišta, tako i uoči glavne rasprave $^{57}$, trebalo bi u manje složenim predmetima biti sasvim dostatno da se ispuni pripremna svrha prethodnog postupka. ${ }^{58}$ Iako načelno nepotrebno, usmeno pripremno ročište u takvim jednostavnijim sporovima moglo bi biti svrsishodno ako postoje naznake da se spor riješi mirnim putem, za što je sigurno povoljnija usmena forma, ali to bi ovisilo o sudskoj ocjeni svih okolnosti. ${ }^{59}$

Naravno, pripremno ročište trebalo bi ostati procesna mogućnost suda $u$ svim onim predmetima koji su činjenično i pravno kompleksni, odnosno u kojima stranke postavljaju velik broj zahtjeva i prigovora ili u kojima je moguće očekivati izvođenje velikog broja dokaza koje je potrebno prikupiti za glavnu raspravu koja očito ne može biti održana istodobno s pripremnim ročištem. To bi se ročište u takvim postupcima moglo nadovezati na pripremne podneske, a moglo bi ih i u potpunosti zamijeniti. Pritom bi o ocjeni individualnih okolnosti svakog pojedinog predmeta, a ne proizvoljnoj procjeni zakonodavca, trebao ovisiti potreban broj pripremnih ročišta. Također, i u takvim predmetima uštede u vremenu i novcu mogle bi se osigurati korištenjem audiovizualnih uređaja, odnosno održavanjem ročišta na daljinu, za što je potrebno dodatno ulaganje $\mathrm{u}$ infrastrukturu i tehnološka rješenja. Uštede u vremenu mogle bi se postići i propisivanjem dužnosti suda da zakaže pripremno ročište u roku od 60 dana

Pro futuro: Betrachtungen über Probleme der Civilproceßreform in Österreich, Deuticke, Leipzig, 1891, str. 88 seqq). Čini se, barem prema najavama, da hrvatski zakonodavac ne misli izvući pouke iz lošeg primjera slovenskog zakonodavca koji je pokušao pisani europski spor male vrijednosti preslikati na domaće prilike umjesto da ga pojednostavni jednim jednostavnim ročištem (Galič, A., Prve praktične izkušnje z novelo ZPP-D v postopku na prvi stopnji, Pravni letopis, br. 1, 2009., str. 72). Ova složena tema, ipak, traži zasebno istraživanje. Naime, sve prethodno rečeno traži da se redefiniraju i sporovi koji se mogu smatrati bagatelnima. Više o problemu razmjernosti u kontekstu sporova male vrijednosti vidi Brozović, op. cit. u bilj. 54, str. $213-223$.

58 Pisana razmjena podnesaka mogla bi se koristiti ne samo za raspravljanje o procesnim pretpostavkama, već i konkretnim očitovanjima stranaka o meritumu samog spora.

59 Kao pomoć prilikom odluke je li primjereno u jednostavnijem sporu održati pripremno ročište radi mirnog rješenja spora mogli bi poslužiti kriteriji iz čl. 186.d. st. 1 . ZPP-a prema kojima sud može uputiti stranke na mirenje kad se to čini primjerenim “uvažavajući sve okolnosti, posebno interes stranaka i trećih osoba vezanih uz stranke te trajnost njihovih odnosa i upućenost jednih na druge...”. 
od primitka odgovora na tužbu, kao što je dužan tužbu poslati tuženiku na pisani odgovor. ${ }^{60}$

\section{b) Preobrazba uloge suda, stranaka i odvjetnika u prethodnom postupku}

S obzirom da je između suda s jedne strane te stranaka i njihovih odvjetnika s druge strane potreban dijalog, on bi se mogao potaknuti uvođenjem plana upravljanja postupkom, odnosno procesnog kalendara, karakterističnog za najbolje komparativne prakse, a kod nas već sad i za arbitražu. ${ }^{61}$ Takav bi plan upravljanja postupkom osim predmeta spora, odnosno iznesenih zahtjeva utemeljenih na tužbenoj osnovi te predmeta raspravljanja, odnosno spornih odlučnih činjenica, mogao naznačiti dokazna sredstva potrebna za utvrđivanje tih činjenica te rokove za pripremne dokazne radnje (npr. uplatu predujma troškova, imenovanje vještaka, izradu pisanog nalaza i mišljenja). Taj bi plan upravljanja postupkom mogao sadržavati i vrijeme održavanja ročišta te eventualno vrijeme za ulaganje pisanih podnesaka ako su potrebni.

Njegova izrada ne bi trebala biti obvezna u jednostavnim predmetima koji bi se mogli riješiti, primjerice, istodobnim održavanjem pripremnog ročišta i ročišta za glavnu raspravu, izvođenjem svih predloženih dokaza i zaključenjem glavne rasprave. U predmetima u kojima je ovakav procesni kalendar potreban logično je da do izrade i potvrde ovog plana dolazi na pripremnom ročištu na kojem stranke sudu mogu dati i svoje prijedloge. Sud bi trebao preuzeti odgovornost za izradu nacrta te nakon raspravljanja sa strankama donijeti posebno rješenje ili u zapisnik unijeti njegov osnovni sadržaj. Ovakvim pristupom dijeli se odgovornost za tijek postupka jer stranke odmah znaju koje radnje moraju poduzeti i u kojem roku. Time se postiže i predvidljivost trajanja postupka, što je važno i radi predvidivosti njegovih troškova. Konačno, takav otvoreni pristup suda preduvjet je i primjene pravila o procesnim prekluzijama.

$\mathrm{S}$ time $\mathrm{u}$ vezi napominjemo kako se pravovremenost iznošenja činjenica i dokaznih prijedloga u našem postupku ocjenjuje samo s obzirom na krivnju stranaka, zbog čega se oni nakon zaključenja prethodnog postupka mogu odbiti

60 Čl. 284. st. 1. ZPP-a. Smatramo to boljim rješenjem nego unaprijed propisati rok za održavanje pripremnog ročišta. Time se sud potiče na aktivnost uz zadržavanje dovoljnog stupnja fleksibilnosti u postupku.

${ }_{61}$ Usporedi čl. 33. Pravilnika o arbitraži pri Stalnom arbitražnom sudištu Hrvatske gospodarske komore (Narodne novine, br. 129/2015, 50/2017). 
i kad takvo prihvaćanje ne bi bilo od utjecaja na tijek postupka. ${ }^{62}$ Smatramo da je hrvatskom postupku potreban fleksibilan pristup karakterističan za komparativne uzore, prema kojem bi mogućnost naknadnog iznošenja činjenica i dokaznih prijedloga ovisila u prvom redu o tome je li ono od utjecaja na tijek i trajanje postupka (drugim riječima: dovodi li do odgode ročišta), a tek podredno o krivnji stranaka. Čak i kad ne postoji krivnja stranaka, trebalo bi uzeti u obzir i potrebu postizanja procesne razmjernosti pa odbijati zakašnjelo iznošenje činjenica i dokaznih prijedloga kad je stranka već imala dovoljno prilike dokazati osnovanost svojih zahtjeva, odnosno prigovora. ${ }^{63}$

\section{c) Vanjski utjecaj na motivaciju procesnih subjekata}

Ovakva prilagodba uloge procesnih subjekata nemoguća je ako se istodobno ne utječe na njihovu motivaciju da postupaju u skladu s procesnim pravilima. $U$ tom bi smislu valjalo razmisliti da se prilagode okvirna mjerila za ocjenjivanje rada sudaca, stavljanjem naglaska na brzinu donošenja pojedinih vrsta odluka, umjesto na njihov broj, za što u okviru sustava eSpis nisu potrebne velike prilagodbe. ${ }^{64}$ Također, postojeći sustav nadoknade troškova koji ovisi isključivo o Tarifi o nagradama i naknadi troškova za rad odvjetnika ${ }^{65}$ nedovoljno potiče mirno rješenje spora, dok istodobno doprinosi neučinkovitom provođenju postupka. ${ }^{66}$ Potencijalni izlaz iz problema bilo bi rješenje prema kojem bi se odvjetničkoj profesiji prepustilo da autonomno odredi koliko i kako želi naplaćivati svoje usluge, dok bi zakonska pravila postavila maksimalan iznos troškova koji je

62 Jedinu iznimku predstavljaju zakašnjeli podnesci nakon što je sud zatražio očitovanje o određenim pitanjima koji će se uzeti u obzir "ako njihovo uzimanje u obzir ne bi dovelo do odugovlačenja postupka” (čl. 299.a st. 3. ZPP-a).

63 Ovo su kriteriji za koje smatramo da bi bili prikladni i za ostale procesne prekluzije, kao u slučaju objektivne preinake. Smatramo da treba preispitati i nemogućnost subjektivne preinake, odnosno isticanja protutužbe i prigovora radi prijeboja nakon zaključenja prethodnog postupka jer nema razloga da se te parnične radnje spriječe ako ne bi bile od utjecaja na tijek postupka, odnosno tražile zakazivanje i održavanje novih ročišta.

64 Sud koji u roku od mjesec dana donese rješenje o odbačaju tužbe ili o relativnoj nenadležnosti jednako učinkovito postupa kao sud koji donese meritornu odluku u složenom sporu u roku od godine i pol dana. Broj odluka određene vrste trebao bi biti posljedica, a ne cilj kvalitetnog rada sudaca.

65 Narodne novine, br. 142/2012, 103/2014, 118/2014 i 107/2015.

Uzelac, op. cit. u bilj. 3, str. $60-63$. 
dužna nadoknaditi protivna strana, honorirajući pritom učinkovito postupanje i poželjan ishod postupka. ${ }^{67}$

Najvažnije od svega, bilo bi poželjno da svaka sljedeća reforma bude poduzeta planirano, uz dovoljni vakacijski rok i financijska ulaganja u edukaciju stručnih kadrova, koja će omogućiti da duh reforme zaživi među sucima, odvjetnicima i drugim pravnim profesionalcima.

\section{LITERATURA}

Abramović, A., Poželjna mjera utjecaja suda u odnosu na dokazivanje i neke druge parnične radnje stranaka, Hrvatska pravna revija, lipanj 2005., str. 90-97.

ALI/UNIDROIT Načela transnacionalnog građanskog postupka

ALI/UNIDROIT Pravila transnacionalnog građanskog postupka

Basrak, B.; Varga, I., Benfordov zakon, Math.e, vol. 23, br. 1, 2013., str. 1-6.

Bentham, J., Letter V: On the Bill Called Lord Eldon's., u: Bowring, J. (ur.), The Works of Jeremy Bentham, vol. 5, William Tait, Edinburgh, 1843., str. 90-92.

Bilić, V., Novela Zakona o parničnom postupku iz 2013., Informator, vol. 61, br. 6156, 6. ožujka 2013., str. 1-2.

Bratković, M., Građansko pravosuđe u službi građana, u: Barbić, J. (ur.), Europska budućnost hrvatskog građanskog pravosuđa, HAZU, Zagreb, 2019., str. 161-183.

Brozović, J., Priprema i organizacija raspravljanja u parničnom postupku, doktorska disertacija, Pravni fakultet, Zagreb, 2021.

Bugarin, B., Osvrt na Novelu Zakona o parničnom postupku iz 2008., Hrvatska pravna revija, prosinac 2008., str. 90-104.

Dika, M., Građansko parnično pravo. Parnične radnje, V. knjiga, Narodne novine, Zagreb, 2008.

Dika, M.; Uzelac, A., Zum Problem des richterlichen Aktivismus in Jugoslawien, Zbornik Pravnog fakulteta u Zagrebu, vol. 40, br. 4, 1990., str. 391-416.

Economides, K.; Haug, A. A.; McIntyre, J., Toward Timelessness in Civil Justice, Monash University Law Review, vol. 41, br. 2, 2015., str. 414-440.

67 Primjerice, naknada bi mogla, kao u Njemačkoj (Wagner, G., Litigation costs and their recovery: the German experience, Civil Justice Quarterly, vol. 28, br. 3, 2009.), ovisiti o razvoju procesnih stadija umjesto broju radnji, a mogla bi se uvećati u postupcima u kojima je sklopljena sudska nagodba. To ne bi spriječilo odvjetnika da ugovori višu naknadu ili drukčiji način obračuna naknade, ali uz obavijest stranci da neće moći ostvariti nadoknadu svih troškova postupka. Time se potiče tržišno natjecanje, ali istodobno i koncentracija te, posljedično, razmjernost troškova postupka. 
ELI/UNIDROIT Transnacionalna pravila građanskog postupka; dostupno na https://www.unidroit.org/instruments/civil-procedure/eli-unidroit-rules/ (16.12.2021.).

Ervo, L., Changing Civil Proceedings - Courts Service or State Economy, u: Carpi, F. et al., Recent trends in economy and efficiency of civil procedure: materials of international conference, Vilnius University, Vilnius, 2013., str. 51-71.

European judicial systems: Efficiency and quality of justice. CEPEJ STUDIES No. 26, 2018.

Fasching, H. W., Lehrbuch des österreichischen Zivilprozeßrechts, 2. Aufl., Manzsche Verlag, Beč, 1990.

Functional Specifications Report for Computerization in Zagreb Municipal Court of The Republic of Croatia, NCSC, 2001.

Galič, A., Prve praktične izkušnje z novelo ZPP-D v postopku na prvi stopnji, Pravni letopis, br. 1, 2009., str. 55-76.

García Odgers, R., El Case Management en perspectiva comparada. Teoría, evolución histórica, modelos comparados y un caso en desarrollo, Tirant lo Blanch, Valencia, 2020.

Hodges, C., The Europeanisation of Civil Justice: Trends and Issues, Civil Justice Quarterly, vol. 26, 2007., str. 96-123.

Klein, F., Pro futuro: Betrachtungen über Probleme der Civilproceßreform in Österreich, Deuticke, Leipzig, 1891.

Kramer, X. E., The Structure of Civil Proceedings and Why It Matters: Exploratory Observations on Future ELI-UNIDROIT European Rules of Civil Procedure, Uniform Law Review, vol. 19, br. 2, 2014., str. 1-22.

Leubsdorf, J., The Myth of Civil Procedure Reform, u: Zuckerman, A. A. S. (ur.), Civil Justice in Crisis: Comparative Perspectives of Civil Procedure, Oxford University Press, Oxford, 1999., str. 53-70.

Merry, S. A., The Seductions of Quantification. Measuring Human Rights, Gender Violence, and Sex Trafficking, University of Chicago Press, Chicago, London, 2016.

Nylund, A., Introduction to the Preparatory Stage of Civil Proceedings, u: Ervo, L.; Nylund, A. (ur.), Current Trends in Preparatory Proceedings. A Comparative Study of Nordic and Former Communist Countries, Dordrecht, Heidelberg, New York, London, Springer, 2014., str. 1-18.

Pavlović, M., Utvrđivanje stranačke istine u parničnom postupku s posebnim osvrtom na primjenu načela otvorenog pravosuđenja, Hrvatska pravna revija, ožujak 2004., str. 83-94.

Pravilnik o arbitraži pri Stalnom arbitražnom sudištu Hrvatske gospodarske komore (Narodne novine, br. 129/15, 50/17). 
Preporuka Vijeća Europe br. R(84)5

Rechberger, W. H., Zivilprozessrecht, 8. izd., Manz, Beč, 2010.,

Storme, M., A Single Civil Procedure for Europe: A Cathedral Builders' Dream, Ritsumeikan Law Review, International Edition, 2005., str. 87-100.

Stürner, R., Parteiherrschaft versus Richtermacht - Materielle Prozessleitung und Sachverhaltsaufklärung im Spannungsfeld zwischen Verhandlungsmaxime und Effizienz, Zeitschrift für Zivilprozess, vol. 123, br. 2, 2010., str. 147-162.

Šagovac, A., Prekluzije sa zaključenjem prethodnog postupka, Informator, vol. 63, br. 6388, 19. listopada 2015., str. 12-13.

Triva, S.; Dika, M., Građansko parnično procesno pravo, Narodne novine, Zagreb, 2004.

Udovičić, M. et al., Što treba znati kada izračunavamo koeficijent korelacije?, Biochemia Medica, vol. 17, br. 1, 2007., str. 10-15.

Uzelac, A., Croatia: Omnipotent Judges as the Cause of Procedural Inefficiency and Impotence, u: van Rhee, C.H.; Fu, Y. (ur.), Civil Litigation in China and Europe. Essays on the Role of the Judge and the Parties, Springer, Dordrecht, Heidelberg, New York, London, 2014., str. 197-221.

Uzelac, A., Delays and Backlogs in Civil Procedure. A (South) East European Perspective, Revista de Processo, vol. 39, br. 238, 2014., str. 39-64.

van Rhee, C. H.; Fu, Y., The Role of the Judge and the Parties in Civil Litigation in China and Europe: An Introduction, u: van Rhee, C.H.; Fu, Y. (ur.), Civil Litigation in China and Europe. Essays on the Role of the Judge and the Parties, Springer, Dordrecht, Heidelberg, New York, London, 2014., str. 1-10.

Verkerk, R. R., What is Judicial Case Management, u: van Rhee, C. H. (ur.), Judicial Case Management and Efficiency in Civil Litigation, Intersentia, Antwerp, Oxford, Portland, 2008., str. 27-56,

Wagner, G., Litigation costs and their recovery: the German experience, Civil Justice Quarterly, vol. 28, br. 3, 2009., str. 367-388.

Waxse, D. J., Cooperation - What Is It and Why Do It?, Richmond Journal of Law \& Technology, vol. XVIII, br. 3, 2012., str. 1-18.

Zakon o parničnom postupku (Službeni list SFRJ, br. 4/1977, 36/1977, 36/1980, 6/1980, 69/1982, 43/1982, 58/1984, 74/1987, 57/1989, 20/1990, 27/1990, 35/1991, Narodne novine, br. 53/1991, 91/1992, 112/1999, 129/2000, 88/2001, 117/2003, 88/2005, 02/2007, 84/2008, 96/2008, 123/2008, 57/2011, 148/2011, 25/2013, 89/2014 i 70/19)

Zrilić, Z., Načélo otvorenog pravosuđenja u svjetlu predloženih izmjena i dopuna Zakona o parničnom postupku, Hrvatska pravna revija, siječanj 2003., str. 1-9. 
Zrilić, Z., Prethodni postupak prema Nacrtu prijedloga Zakona o izmjenama i dopunama Zakona o parničnom postupku, Informator, vol. 56, br. 5661, 7. lipnja 2008., str. 8-9.

Zuckerman, A. A. S., Civil Justice in Crisis: Comparative Dimensions of Civil Procedure, u: Zuckerman, A. A. S. (ur.), Civil Justice in Crisis: Comparative Perspectives of Civil Procedure, Oxford University Press, Oxford, 1999.

Zuckerman, A. A. S., Court Adjudication of Civil Disputes: A Public Service to be Delivered With Proportionate Resources, Within a Reasonable Time and at Reasonable Cost, u: van Rhee, C. H.; Heirbaut, D.; Storme, M. (ur.), The French Code of civil procedure (1806) after 200 years, The civil procedure tradition in France and abroad, Kluwer, Mechelen, 2008., str. 435-468.

Zuckerman, A. A. S., On Civil Procedure: Principles of Practice, 3. izd., Sweet and Maxwell, London, 2013. 


\section{Summary}

\section{Juraj Brozović"}

\section{DID CROATIAN PREPARATORY PROCEEDINGS CONTRIBUTE TO THE CONCENTRATION AND SHORTER DURATION OF CIVIL PROCEEDINGS?}

After more than ten years of application of the rules introducing the preparatory proceedings, which have been the subject of several amendments to the Civil Procedure Act, there is a need to examine whether such a gradual structural change has indeed led to concentrated and shorter proceedings with fewer hearings. The official data published by the Ministry of Justice of the Republic of Croatia, later by the Supreme Court of the Republic of Croatia, do not include data on the duration of the proceedings or the reason for such situation, nor do they explain how long its individual stages last or how many hearings are held in an average proceeding. Our research offers an innovative methodology and presents the results of extensive empirical research, which, on the one hand, considers actual data on the duration of proceedings and the number of hearings from the official case record system and, on the other hand, analyzes a representative sample of cases of the largest Croatian municipal court, trying to identify potential causes of inefficient proceedings. Finally, this paper proposes the necessary changes to the rules on the preparatory proceedings, as well as in the mentality of judges, lawyers and other legal professionals involved in the proceedings.

Key words: preparatory proceedings, empirical research, duration of proceedings, number of hearings, loyal cooperation, proportionality

\footnotetext{
* Juraj Brozović, Ph. D., Assistant, Faculty of Law, University of Zagreb, Trg Republike Hrvatske 3, 10000 Zagreb; jbrozovic@pravo.hr;

ORCID ID: orcid.org/0000-0003-2362-4580
} 